\title{
Affording States a Margin of Appreciation: Comparing the European Court of Human rights and the Inter-American Court of Human Rights
}

\section{Introduction}

One of the great intellectual mysteries in international human rights law is why the InterAmerican Court of Human Rights (IAmCtHR) under the American Convention on Human Rights(AmCHR) has not invoked the concept of the margin of appreciation (MoA) - a concept which has become the central conceptual doctrine in the ECHR institutional and jurisprudential architecture $^{1}$ and has spread to other international decision making bodies. ${ }^{2}$ This article critiques the existence and operation of the MoA within the ECHR system and submits that the concept should be applied by the IAmCtHR under the AmCHR.

Although the MoA was judicially developed by the European Court of Human Rights (ECtHR) it has now received express affirmation and support from the States parties to the

\footnotetext{
${ }^{1}$ See D. Spielmann, 'Allowing the Right Margin the European Court of Human Rights and the National Margin of Appreciation Doctrine: Waiver or Subsidiarity of European Review?' (2011-12) 14 Cambridge Yearbook of European Legal Studies 381 (updated at http://www.echr.coe.int/Documents/Speech_20140113_Heidelberg_ENG.pdf); Legg, The Margin of Appreciation in International Human Rights Law Deference and Proportionality (Oxford: OUP, 2012); Y. Arai-Takahashi, The Margin of Appreciation Doctrine and the Principle of Proportionality in the Jurisprudence of the ECHR (.....: Intersentia, 2002); ibid, 'The Margin of Appreciation Doctrine: A Theoretical Analysis of Strasbourg's Variable Geometry', in A. Follesdal et al (eds) Constituting Europe (Cambridge: CUP, 2013) 62; Greer, 'The Margin Of Appreciation: Interpretation And Discretion Under The European Convention On Human Rights (Council of Europe, 2000), available at http://www.echr.coe.int/LibraryDocs/DG2/HRFILES/DG2-EN-HRFILES17(2000).pdf; Hutchinson, 'The Margin of Appreciation Doctrine in the European Court of Human Rights' (1999) 48 International and Comparative Law Quarterly 638; A. McHarg, 'Reconciling Human Rights and the Public Interest: Conceptual Problems and Doctrinal Uncertainty in the Jurisprudence of the European Court of Human Rights' (1999) 62 Modern Law Review 671; Seminar Report on The Doctrine of the Margin of Appreciation under the European Convention on Human Rights: Its Legitimacy in Theory and Application in Practice (1998) 19 Human Rights Law Journal 1-36; N. Lavender, 'The Problem of the Margin of Appreciation' (1997) 2 European Human Rights Law Review 380; C. Yourow, The Margin Of Appreciation Doctrine In The Dynamics Of European Human Rights Jurisprudence (.....: Kluwer, 1996); R. St. J. MacDonald, 'The Margin of Appreciation' in MacDonald et al. (eds), The European System For The Protection Of Human Rights (Dordrecht: Nijhoff, 1993) 83.

${ }^{2}$ See Y. Shany, 'Towards a General Margin of Appreciation Doctrine in International Law' (2005) 16 European Journal of International Law 907.
} 
ECHR. The Brighton Declaration on the Future of the ECtHR $(2012)^{3}$ contained seven references to the 'margin of appreciation' and six references to 'subsidiarity'. Protocol 15 ECHR (2014) added to the Preamble of the ECHR a reference to the principle of subsidiarity and the doctrine of the MoA:

\begin{abstract}
Affirming that the High Contracting Parties, in accordance with the principle of subsidiarity, have the primary responsibility to secure the rights and freedoms defined in this Convention and the Protocols thereto, and that in doing so they enjoy a margin of appreciation, subject to the supervisory jurisdiction of the European Court of Human Rights established by this Convention. ${ }^{4}$
\end{abstract}

Even before Protocol 15 had come into force the ECtHR had stressed the 'crucial importance' of its subsidiary role and relied on it justify it departing from the general principle that the exhaustion of domestic remedies requirement should be assessed with reference to the time at which the application was lodged. ${ }^{5}$

Following these introductory comments, Section 2 describes the concept and use of the MoA. Section 3 considers the explanations advanced for using the MoA. Section 4 assesses the role of consensus or the lack thereof in determining the MoA. Section 5 assesses various critiques of the MoA. Section 6 raises the issue of the Non-Use of the MoA by the IAmCtHR. Section 7 critiques a series of possible explanations. Section 8 analyses a series of jurisprudential similarities and differences between the ECtHR/ ECHR and the IAmCtHR / AmCHR and considers whether they justify or explain the non-use of the MoA by the HRC. Section 9 offers some concluding reflections.

\title{
2. The Concept of the Margin of Appreciation
}

A. The Concept

\footnotetext{
${ }^{3}$ Available at http://hub.coe.int/20120419-brighton-declaration.

${ }^{4}$ See A. Mowbray, 'European Court of Human Rights: May 2012-April 2013' (2013) 19 European Public Law 643.

${ }^{5}$ In Stella v. Italy, A. 49169/09 and 10 other applications, and Rexhepi v. Italy A. 47180/10 and seven other applications, (25 September 2014) the ECtHR considered that there were grounds in the present case for departing from the general principle and that this exception could apply to all similar cases pending before it.
} 
The MoA is a doctrine of judicial self-restraint applied by the ECtHR. ${ }^{6}$ It was originally applied in the context of derogations ${ }^{7}$ but has now spread to the interpretation of the scope of obligations under all of the substantive Articles, even obligations under non-derogable ones such as Articles $2^{8}$ and $3,{ }^{9}$ and the accessory protection against discrimination in Article $14 .{ }^{10}$ In the famous Handyside $v U K(1976)$ case the ECtHR explained that,

This margin [of appreciation] is given both to the domestic legislator ("prescribed by law') and to the bodies, judicial amongst others, that are called upon to interpret and apply the laws in force... The domestic margin of appreciation... goes hand in hand with a European supervision. Such supervision concerns both the aim of the measure challenged and its 'necessity'; it covers not only the basic legislation but also the decision applying it, even one given by an independent court. ${ }^{11}$

The MoA is most commonly applied in the context of limitations on rights. ${ }^{12}$ It has assumed even more significance as the ECtHR, through its case law, has expanded the scope of ECHR

\footnotetext{
${ }^{6}$ See J.-P. Cot, 'Margin of Appreciation' Max Planck Encyclopaedia of Public International Law, available at http://opil.ouplaw.com/view/10.1093/law:epil/9780199231690/law9780199231690-e1438?rskey=9uwCFk\&result=3\&q=\&prd=EPIL.

7 ... it falls to each Contracting State, with its responsibility for "the life of [its] nation", to determine whether that life is threatened by a "public emergency" and, if so, how far it is necessary to go in attempting to overcome the emergency. By reason of their direct and continuous contact with the pressing needs of the moment, the national authorities are in principle better placed than the international judge to decide both on the presence of such an emergency and on the nature and scope of the derogations necessary to avert it. Accordingly, in this matter a wide margin of appreciation should be left to the national authorities.

Nonetheless, Contracting Parties do not enjoy an unlimited discretion... (A and Others $v$. UK, A. 3455/05 [GC], para 173). See M. Elliott, 'UK: The "War on Terror"' (2010) 8 International Journal of Constitutional Law 131.

${ }^{8}$ See S. Skinner, 'Deference, Proportionality and the Margin of Appreciation in Lethal Force Cases under Article 2 ECHR' (2014) EHRLR 32; Vo v. France, A. 53924/00 [GC].

${ }^{9}$ See Jalloh v. Germany, A. 54810/00 [GC] (2006); ' within the limits of the Convention, the choice of the means to secure compliance with Article 3 in the sphere of the relations of individuals between themselves is in principle a matter that falls within the domestic authorities' margin of appreciation, provided that criminal-law mechanisms are available to the victim', Valiuliene v. Lithuania, A. 33234/07, 26 March 2013, para 85; Legg, supra n 00, 204-210.

${ }^{10}$ See O. Mjöll Arnardóttir, 'The Differences that Make a Difference: Recent Developments on the Discrimination Grounds and the Margin of Appreciation under Article 14 of the ECHR' (2014) 14 Human Rights Law Review 647.

111 EHRR (1979-80) 737, para 48.

${ }^{12}$ See J. Kratochvíl 'The Inflation of the Margin of Appreciation by the European Court of Human Rights' (2011) Netherlands Quarterly of Human Rights 324; O. Bakircioglue, 'The
} 
rights through its interpretation of the ECHR as a 'living instrument' 13 and thereby developed the scope of procedural ${ }^{14}$ and positive obligations. ${ }^{15}$ With respect to positive obligations the States enjoy a wide margin of appreciation in determining the steps to be taken to ensure compliance with the ECHR with due regard to the needs and resources of the community and of individuals. ${ }^{16}$

In assessing whether there exists a pressing social need for the measure in question and, in particular, whether the interference was proportionate ${ }^{17}$ to the legitimate aim pursued, regard has to be had to the 'fair balance' which has to be struck between the relevant competing interests and in respect of which the State enjoys a MoA. ${ }^{18}$ The breadth of the MoA to be accorded to the State can be crucial to the ECtHR's conclusion as to whether the impugned prohibition struck a fair balance. ${ }^{19}$ In delimiting the extent of the MoA in a given case, the ECtHR has regard to what is at stake therein. ${ }^{20}$ Where a particularly important facet of an individual's existence or identity is at stake, the MoA allowed to the State will normally

Application of the Margin of Appreciation Doctrine in Freedom of Expression and Public morality Cases' (2007) 8 German Law Journal 711.

${ }^{13}$ See N. Bratza, 'Living instrument or dead letter - the future of the ECHR' (2014) European Human Rights Law Review 116; K. Dzehtsiarou, 'European Consensus and the Evolutive Interpretation of the ECHR' (2011) 12 (10), German Law Journal, 1730.

${ }^{14}$ Procedural requirements to comply with and ensure the effectiveness of substantive obligations are now highly developed, see E. Brems, 'Procedural Protection: An Examination of the Procedural Safeguards read into Substantive Convention Rights' in E. Brems and J Gerards (eds), Shaping Rights in the ECHR: The Role of the ECtHR in Determining the Scope of Human Rights (Cambridge: CUP, 2013) 137.

${ }^{15}$ See A. Mowbray, The Development of Positive Obligations Under the European Convention on Human Rights by the European Court of Human Rights (Oxford: Hart, 1994); P. Gallagher, 'The ECHR and the Margin of Appreciation' (2012) available at <http://ssrn.com/abstract=1982661> ${ }^{16}$ See Abdulaziz v. UK, A. 9214/80, 9473/81, 9474/81, (1985) 7 EHRR 471, para 67; L. Lavrysen, 'The Scope of Rights and the Scope of Obligations' in Brems and Gerards, supra $\mathrm{n}$ 00, 162.

${ }^{17}$ Spielmann, supra n. 00, observes that 'the proportionality principle constitutes the strongest bulwark against the over-use of the margin of appreciation doctrine', at 22. See also S. Tsakyrakis, 'Proportionality: An Assault on Global Human Rights' (2009) 7 International Journal of Constitutional Law 468.

${ }^{18}$ See J. Christofferson, Fair Balance: Proportionality, Subsidiarity and Primarity in the ECHR (2009); A. Mowbray, 'A Study of the Principle of Fair Balance in the Jurisprudence of the European Court of Human Rights' (2010) Human Rights Law Review 289. ${ }^{19} A, B$ and $C$ v Ireland [GC], A. 25579/05, para 231 (concerning access to abortion). ${ }^{20}$ Manoussakis and Others v. Greece, A. 18748/91 (26 September 1996), para 44, Reports 1996-IV (concerning the authorisation of religious establishments); Leyla Sahin v. Turkey [GC], A. 30943/96, para 110 (concerning the wearing of Islamic headscarves in educational institutions). 
be restricted. ${ }^{21}$ So too where measures, such as deprivation of legal capacity, have such an adverse effect on an individual's personal autonomy. ${ }^{22}$ If the process was seriously deficient in some respect, the conclusions of the domestic authorities are more open to criticism. ${ }^{23}$

In terms of whether the MoA applies and its width, it will be significant if the relevant law or policy is considered to reflect the 'profound moral views of the people of the state' 24 or 'concerns a question about the requirements of morals' ${ }^{25}$ There will usually be a wide MoA if the State is required to strike a balance between competing private and public interests or competing rights and interests that are protected under the ECHR. ${ }^{26}$ An element to which the ECtHR increasingly directs its attention is whether the national decision-making process, seen as a whole, provides for the requisite protection by weighing up the interests at stake in detail and in depth. ${ }^{27}$ The ECtHR may also afford a wider MoA during a particular historical background, such as during a transition to democracy. ${ }^{28}$ However, there will come a point where the transition is considered to have been sufficiently consolidated and the margin will narrow. ${ }^{29}$ The application of the MoA means that some restrictions on rights may vary from one State to another, or even from one region to another within the same State, especially a State that has opted for a federal type of political organisation. ${ }^{30}$ In such cases only serious reasons could lead it to substitute its own assessment for that of the national and local authorities, which are closer to the realities of their country, for it would thereby lose sight of the subsidiary nature of the Convention system. ${ }^{31}$

${ }^{21}$ Evans v UK [GC], A. 6339/05, (2008) 46 EHRR 34, para 77 (concerning an ex-partner's consent for the use of frozen embryos).

${ }^{22}$ Ivinović v. Croatia, A. 13006/13, para 37 (18 Sept 2014).

${ }^{23}$ Ibid., para 46 (the national courts, in depriving partially the applicant of her legal capacity, did not follow a procedure which could be said to be in conformity with the guarantees under Article 8); Sahin v. Germany, A. 30943/96, para 46 et seq. (11 October 2001); SalontajiDrobnjak v. Serbia, A. 36500/05, para 143 (13 October 2009).

${ }^{24} A, B$ and $C$ v Ireland [GC), A. 25579/05, para 241. The ECtHR considered that there was not sufficiently evidence of a change in the views of the Irish people concerning the grounds for lawful abortion in Ireland, as to displace the State's opinion to the Court on the exact content of the requirements of morals in Ireland, ibid., para 241. For criticism of the deference to internal moral views see the partly dissenting opinion of six judges; Ryan, infra n 00 .

${ }^{25}$ Stübing v Germany, supra n. 102, para 61.

${ }^{26}$ Evans v. UK [GC], A. 6339/05, para 77, ECHR 2007-I; Eweida and Others v UK, A. 48420/10, 59842/10, 51671/10 and 36516/10), para 109.

${ }^{27}$ Fernandez-Martinez v. Spain [GC], A. 56030/07, paras 123-53, (12 June 2014).

${ }^{28}$ Rekvényi v. Hungary [GC], A. 25390/94, paras 44-50 (decided in May 1999).

${ }^{29}$ See Vajnai v. Hungary, A. 33629/06, paras 48-58 (decided in July 2008).

${ }^{30}$ Mouvement Raëlien Suisse v. Switzerland, [GC] A. 16354/06, paras 64-5.

${ }^{31}$ Ibid. 
If a restriction on fundamental rights applies to a particularly vulnerable group in society, who have suffered considerable discrimination in the past, then the State's MoA is substantially narrower and it must have very weighty reasons for the restrictions in question. This approach has been applied, for example, in the context of those suffering different treatment on the ground of their gender, ${ }^{32}$ race, ${ }^{33}$ sexual orientation ${ }^{34}$ or mentally disability. ${ }^{35}$ The reason for this approach, which questions certain classifications per se, is that such groups were historically subject to prejudice with lasting consequences, resulting in their social exclusion. Such prejudice may entail legislative stereotyping which prohibits the individualised evaluation of their capacities and needs. ${ }^{36}$

It is critical to emphasize that the MoA is an instrument of supervision - European supervision goes 'hand in hand' with it. The MoA is not an instrument of surrender or abdication. Even if the applicable MoA is wide, it is not all-embracing. ${ }^{37}$ European supervision is not limited to ascertaining whether the State exercised its discretion reasonably, carefully and in good faith. These elements are necessary but not sufficient. The ECtHR commonly uses the language of whether the State has remained within, or not overstepped, an 'acceptable' MoA. ${ }^{38}$

The ECtHR looks at the interference complained of in the light of the case as a whole and determines whether it was 'proportionate to the legitimate aim pursued' and whether the reasons adduced by the national authorities to justify it are 'relevant and sufficient'. The ECtHR has to satisfy itself that the standards applied by national authorities were in conformity with the principles embodied in the substantive ECHR norms and decisions must have been based on an acceptable assessment of the relevant facts. ${ }^{39}$ It is notable that there are many cases in which the ECtHR affords states a wide MoA but then decides that states have not remained within it, usually due to disproportionality ${ }^{40}$ or the lack of a fair balance,

\footnotetext{
${ }^{32}$ Abdulaziz, Cabales and Balkandali v. the UK, A. Nos. 9214/80; 9473/81; 9474/81, (1985), para 78.

${ }^{33}$ D.H. and Others v. the Czech Republic [GC], A. 57325/00, para 182....

${ }^{34}$ E.B. v. France [GC], A. 43546/02, para 94,

${ }^{35}$ Alajos Kiss v. Hungary, A. 38832/06, (20 May 2010), para 42.

${ }^{36}$ Ibid; Shtukaturov v. Russia, A. 44009/05, para 95, (27 March 2008).

${ }^{37}$ Hirst v. UK (No. 2) [GC], A. 74025/01, para 82).

${ }^{38}$ Alajos Kiss, supra n 00; Odievre v. France, A. 42326/98 [GC] (2003).

${ }^{39}$ Rekvényi v. Hungary [GC], A. 25390/94, para 44.

${ }^{40}$ On the importance of procedural rationalism as part of proportionality see P. Popelier and

C. Van De Heyning, 'Procedural Rationality: Giving Teeth to the Proportionality Analysis' (2013) European Constitutional Law Review 230.
} 
and so there is a violation. ${ }^{41}$ Even where the ECtHR is clear that all agree that it is an area where states have a MoA, reasonable judges may disagree on whether a fair balance has been struck in an individual case. In Jeunesse v. Netherlands ${ }^{42}$ concerned the refusal by the authorities to allow a Surinamese woman married to a Netherlands national, with whom she had three children, to reside in the Netherlands on the basis of her family life in the country. The Court took into consideration that, apart from $\mathrm{J}$, all members of her family were Dutch nationals entitled to enjoy family life with each other in the Netherlands, that $\mathrm{J}$ had been living in the Netherlands for more than 16 years (and the Netherlands authorities had been aware of this), that she had no criminal record and that settling in Suriname would entail a degree of hardship for the family. It further considered that the Netherlands authorities had not paid enough attention to the impact on J's children of the authorities' decision to refuse her request for a residence permit. Indeed, the authorities had failed to take account of and assess evidence on the practicality, feasibility and proportionality of the refusal at issue in order to give effective protection and sufficient weight to the best interests of the children. The central issue was whether, bearing in mind the MoA afforded to States in immigration matters, a fair balance had been struck between the competing interests at stake, namely the personal interests of the $\mathrm{J}$, her husband and their children in maintaining their family life in the Netherlands on the one hand and, on the other, the public order interests of the respondent Government in controlling immigration. In view of the particular circumstances of the case, the majority (14) considered that it was questionable whether general immigration policy considerations of themselves could be regarded as sufficient justification for refusing the applicant residence in the Netherlands. They regarded the circumstances of J's case as exceptional and so concluded that a fair balance had not been struck between the competing interests involved, resulting in a violation by the national authorities of the positive obligations which Article 8 placed on them. A minority of three sharply dissented. ${ }^{43}$ For them the exceptional character of the particular circumstances had overridden most of the previously followed jurisprudential principles; the Court could be seen to be acting as a first-

It has been argued that the absence of a common standard under which to balance incommensurable legislative choices concerning human rights makes the proportionality test unreal, see T. Endicott, 'Proportionality and Incommensurability' in G. Huscroft, B.W. Miller and G. Webber (eds) Proportionality and the Rule of Law: Rights, Justification, Reasoning Cambridge: CUP 2014) 311.

${ }^{41}$ See the cases cited by Kratochvil, supra n 00, 337-40.

${ }^{42}$ A. 12738/10, (3 October 2014).

${ }^{43}$ Joint dissenting opinion of Judges Villiger, Mahoney and Silvis. 
instance immigration court, in disregard of the principle of subsidiarity; the MoA, which was wide in such circumstances, had undergone a 'hot wash' in this case; and finally, 'In replacing the domestic balancing exercise by a strong reliance on the exceptional character of the particular circumstances, the Court is drifting away from the subsidiary role assigned to it by the Convention, perhaps being guided more by what is humane, rather than by what is right.'

\section{B. The Relationship between the MoA and the Standard of Review}

A critical element to appreciate is that the scope of the MoA afforded directly relates to the strictness of review. Broadly speaking, the wider the margin, the less strict the scrutiny ${ }^{44}$ and vice versa. However, this is only a generalisation or starting point. Alajos Kiss v. Hungary ${ }^{45}$ concerned national rules to ensure that only those who were capable of assessing the consequences of their decisions and making conscious and judicious decisions should participate in public affairs by voting. The ECtHR accepted that this was an area in which, generally, a wide MoA should be granted to the national legislature in determining whether restrictions on the right to vote can be justified in modern times and, if so, how a fair balance is to be struck. ${ }^{46}$ In particular, it should be for the legislature to decide as to what procedure should be tailored to assessing the fitness to vote of mentally disabled persons. However, the ECtHR then went on to observe that there was no evidence that the Hungarian legislature had ever sought to weigh the competing interests or to assess the proportionality of the restriction as it stood. ${ }^{47}$ Moreover, it could not accept that an absolute bar on voting by any person under partial guardianship, irrespective of his or her actual faculties, fell within an acceptable MoA. The treatment as a single class of those with intellectual or mental disabilities was a questionable classification, and the curtailment of their rights must be subject to strict scrutiny. An indiscriminate removal of voting rights, without an individualised judicial evaluation and solely based on a mental disability necessitating partial guardianship, could not be considered compatible with the legitimate grounds for restricting the right to vote. ${ }^{48}$

\footnotetext{
${ }^{44}$ See Obukhova v. Russia, A. $34737 / 03$ (8 January 2009).

${ }^{45}$ A. 38832/06, (20 May 2010).

${ }^{46}$ Ibid, para 41.

${ }^{47}$ Ibid.

${ }^{48}$ Ibid., para 44.
} 
The MoA is likely to be wide, and consequently the standard of review less strict, where economic or social policy issues are involved. ${ }^{49}$ Where there is a wide MoA the ECtHR sometimes uses a test of upholding the State's conduct unless the national court has misinterpreted or misapplied the relevant Article of the ECHR or the ECtHR's jurisprudence or it had reached a conclusion that was 'manifestly unreasonable' 50 or 'devoid of reasonable foundation ${ }^{51}$. The issue is not whether the judges of the ECtHR agree with the decision made by the State. Rather it is whether the State has made a defensible, credible, human rightsbased decision that is considered to be within a range of responses which could be deemed to be necessary and proportionate. Where there is a narrow or limited MoA the burden will be on the State to produce compelling and very weighty reasons to justify the interference. ${ }^{52}$ In such cases there may effectively be a 'presumption of a violation of the Convention'.53

\section{Blanket or indiscriminate rules}

As the ECHR system has matured States are usually able to comply with requirements that limitations be prescribed by $\operatorname{law}^{54}$ and have a legitimate aim. Thus it is the ECtHR's analysis of the proportionality of the measures at issue that is often critical. ${ }^{55}$ In a number of the cases the central problem for the ECtHR was that the particular rule was considered to be of a

${ }^{49}$ Powell and Rayner v. UK, A. No. 9310/81 (1990); Stec and Others v. UK [GC], A.65731/01, pr.66 (differential retirement ages based on gender). This will usually be the case in the context of Article 1 of Protocol 1. The MoA has been used in relation to the European Social Charter (1961), see H. Cullen, 'The Collective Complaints System of the European Social Charter: Interpretative Methods of the European Committee of Social Rights' (2009) 9 Human Rights Law Review 61. The UN CeeESCR has stated that, 'Every State party has a margin of discretion in adopting appropriate measures in complying with its primary and immediate obligation to ensure the equal right of men and women to the enjoyment of all their economic, social and cultural rights' (emphasis added), GC 16, pr. 32 (2005) (on the equal right of men and women to the enjoyment of all economic, social and cultural rights).

${ }^{50}$ See $A$ and Others $v$ UK [GC], 3455/05, para 174; Benet Czech, spol r. o. V. Czech Republic, A. 31555/05, para 40.

${ }^{51}$ See National and Provincial Building Society and Others $v$ UK, A. 21319/93, para 80.

${ }^{52}$ See United Communist Party of Turkey and Others v. Turkey, A. 19392/92, para 46; Andrejeva v. Latvia [GC], A. 55707/00, para 87.

${ }^{53}$ Kratochvil, supra n 00, at 351.

${ }^{54}$ A rare recent example of the UK failing the prescribed by law standard was Gillan and Quintan v UK, A. 4158/05, concerning stop and search powers without a requirement of reasonable suspicion. The ECtHR found that the rule operated in practice in an indiscriminate and arbitrary way.

${ }^{55}$ See Legg, supra n 00, 177-99. 
blanket and indiscriminatory nature. Examples include Hirst (No 2) v. UK (prisoner voting), ${ }^{56}$ $S$ and Marper $v . U K^{57}$ (retention of DNA samples and fingerprints in the absence of a criminal conviction) and in Alajos Kiss ${ }^{58}$ (absolute bar on voting by any person under partial guardianship). However, in other situations the ECtHR has accepted that a blanket or indiscriminate rule can be consistent with the ECHR standards. ${ }^{59}$ Even when violations are found, it can be argued that the MoA continues to have a significant influence because the ECtHR leaves considerable discretion to States to devise proportionate schemes in response. ${ }^{60}$ Apart from pilot cases dealing with structural issues, and a small number of cases where it considers there would only be one effective remedy, it normally makes no attempt to devise a legislative scheme to remedy the problem. ${ }^{61}$

\section{Explanations for the Margin of Appreciation}

There are a number of overlapping and related explanations for the MoA. ${ }^{62}$

\section{A. Subsidiarity}

Some aspects of the MoA reflect foundational design and structural issues. First, under the ECHR system, and as now affirmed in Protocol 15, it is States which have the primary responsibility to secure the rights and freedoms defined in the ECHR and its Protocols. ${ }^{63}$ States exercise that responsibility to secure rights via their national authorities, that is, their executives, legislatures and courts. They must engage in the initial assessment or

\footnotetext{
56 [GC], A. 74025/01.

${ }^{57}$ [GC], A. 30562/04 and 30566/04, 4 December 2008.

${ }^{58}$ Supra n 00.

${ }^{59}$ See Animal Defenders International v. UK [GC], A. 48876/08 (2013) (though the majority was only 9:8).

${ }^{60}$ See Scoppolla v. Italy (No. 3), ECtHR [GC], A. 126/2005, paras 93-110 (the Contracting
}

States may decide either to leave it to the courts to determine the proportionality of a measure restricting convicted prisoners' voting rights, or to incorporate provisions into their laws defining the circumstances in which such a measure should be applied). The ECtHR found no violation in that case.

${ }^{61}$ See Harris et al, Law of ECHR, 3rd edn, (Oxford: OUP, 2014) 162-5. Alternatively this remedial aspect could be considered as an aspect of the subsidiary nature of the ECHR system.

${ }^{62}$ See Legg, supra n 00, 15-66.

${ }^{63}$ See text to supra $\mathrm{n} 00$. 
appreciation. Protocol 15 refers to this primary responsibility as being, 'in accordance with the principle of subsidiarity'. By implication the responsibilities of the supervisory mechanisms established by the ECHR in achieving these aims, including the ECtHR and the Committee of Ministers, are subsidiary in nature. Thus for the ECtHR the MoA is a reflection of the 'fundamentally subsidiary role of the Convention mechanism.' ${ }^{\text {'64 }}$

\section{B. Institutional Competence and inter-institutional comity}

A related aspect of subsidiarity is that the ECtHR is an 'international Court'. It is not a national or European Constitutional ${ }^{65}$ or European Supreme Court. ${ }^{66}$ The MoA is, in part, a reflection of the relationship between an international court and national democratic systems,${ }^{67}$ including both their legislatures and their courts ${ }^{68}$ It is arguable that a concept like the MoA is necessary to make the interference by an international court with the sovereignty of democratic states tolerable and politically acceptable. ${ }^{69}$ The language of deference is sometimes used to describe the operation of the MoA but this carries misleading connotations of servility. ${ }^{70}$ It is submitted that institutional competence, comparative institutional advantage or judicial self-restraint are better ways to understand the MoA. The ECtHR has described the MoA as a 'tool to define relations between the domestic authorities and the Court'. ${ }^{71}$ The ECtHR asserts that it is highly respectful of national courts, particularly

${ }^{64}$ SAS v. France [GC], A.43835/11, para 129. On the MoA being rooted in subsidiarity see P. Carozza, 'Subsidiarity as a Structural Principle of International Human Rights Law' (2003) 97 American Journal of International Law 38; P. Mahoney, 'Universality Versus Subsidiarity in the Strasboug Case Law on Free Speech' (1997) European Human Rights Law Review 364 (MoA is inherent in the Convention as an international human rights instrument limiting national democratic discretion to regulate citizens' conduct in the general interest of the community).

${ }^{65}$ See C.M. Zoethout, 'Margin of Appreciation, Violation and (in)compatibility: Why the ECtHR might consider using an alternative mode of adjudication' (2014) 20 European Public Law 309.

${ }^{66}$ See Bates, The Evolution of the European Convention on Human Rights (Oxford: OUP, 2010) 359-80; A. Stone Sweet, 'The ECHR and National Constitutional Reordering' (2011/12) 33 Cardozo Law Review 1859.

${ }^{67}$ See Letsas, supra n 00, 90-2; Shany, supra n at 00; Legg, supra n 00, 691-02.

${ }^{68}$ See Neuman, 'Human Rights and Constitutional Rights: Harmony and Dissonance' (2003) 55 Stanford Law Review 1863.

${ }^{69}$ See generally E. Bates, 'British Sovereignty and the European Court of Human Rights' (2012) 128 Law Quarterly Review 382.

${ }^{70} \mathrm{Cf}$. Lord Hoffmann in $R$ (Pro-Life Alliance) v. BBC, [2004] AC 185 (HL).

${ }^{71} A$ and Others $v$ UK [GC], A. 3455/05, para 184. 
superior courts, which faithfully seek to follow and apply ECHR jurisprudence. In those circumstances, it is respectful in the sense that it will accord their decisions greater deference and will be reluctant to be appearing to micromanage their decisions. ${ }^{72}$ Where a balancing exercise has been undertaken by the national authorities in conformity with the criteria laid down in the ECtHR's case-law, the ECtHR requires strong reasons to substitute its view for that of the domestic courts. ${ }^{73}$ Equally when such a balancing exercise has not been conducted then less strong reasons will be needed. The choice of undertaking such balancing is obviously one that national authorities must make for themselves. However, they cannot complain of discriminatory treatment by the ECtHR if they do not seek to follow the ECtHR's jurisprudence.

Of course, tensions in the relationship between superior national courts and the ECtHR are at their greatest when they adopt diametrically opposed interpretations. However, these are relatively few and far between and both sides appear to view the process as a dialogue to be managed rather than a supremacy context. ${ }^{74}$ Another element of institutional competence is that the ECtHR is not a fourth instance appeal court. ${ }^{75}$

\section{Democratic Societies and Democratic Legitimation}

'Democracy' is the key context or framework within which arguments and reasons have to be articulated within the ECHR system. ${ }^{76}$ The ECtHR has repeatedly explained that pluralism, tolerance and broadmindedness are hallmarks of a 'democratic society'. ${ }^{77}$ Although individual interests must on occasion be subordinated to those of a group, democracy does

\footnotetext{
${ }^{72}$ See N. Bratza, 'The Relationship Between the UK Courts and Strasbourg' (2011) European Human Rights Law Review 505 at 507, giving examples.

${ }^{73}$ See Von Hannover v. Germany (no. 2), A. 40660/08, 60641/08, para 107; Axel Springer AG v. Germany, A. 39954/08, pr.88); Lillo-Stenberg and Sather v. Norway, A. 13258/09, para 44; Mouvement Raëlien v. Switzerland, [GC], A. 16354/06; Aksu v. Turkey [GC], A. 4149/04 and 41029/04; Roche v United Kingdom [GC], A. 32555/96, (2006) 42 EHRR 30, para 120.

${ }^{74}$ See Bratza, supra n 00. [relationship]; Costa, supra n 00; von Hannover v Germany (no. 2); A. 40660/08 and 60641/08) (7 February 2012); R. v Horncastle (Michael Christopher) [2009] UKSC 14; Al-Khawaja and Tahery v. UK [GC], A. 26766/05 and 22228/06.

${ }^{75}$ For a critique see R. Goss, Fair Trial Rights - Article 6 of the European Convention on Human Rights (Oxford: Hart, 2014) 35-64.

${ }^{76}$ Pretty v the United Kingdom [GC], A. 2346/02, (2002) 35 EHRR 1, para 68; Mowbray, 'Contemporary Aspects of the Promotion of Democracy by the ECtHR' (2014) 20 European Public Law 469; Mahoney, supra n 00 (Universality).

77 Şahin v. Turkey [GC], supra n 00, para 108.
} 
not simply mean that the views of a majority must always prevail. A balance must be achieved which ensures the fair and proper treatment of people from minorities and avoids any abuse of a dominant position. Pluralism and democracy must also be based on dialogue and a spirit of compromise necessarily entailing various concessions on the part of individuals or groups of individuals which are justified in order to maintain and promote the ideals and values of a democratic society. ${ }^{78}$ Where these rights and freedoms are themselves among those guaranteed by the ECHR its Protocols, it must be accepted that the need to protect them may lead States to restrict other rights or freedoms likewise set forth in the ECHR. This constant search for a balance between the fundamental rights of each individual is regarded by the ECtHR as the foundation of a democratic society. ${ }^{79}$

Thus, from the ECtHR's perspective, the MoA is a reflection of comparative institutional competence ${ }^{80}$ and the contributions from all levels of legislative and judicial bodies can operate within the MoA. Democratic and political legitimacy, even if broadly understood, push the ECtHR towards respecting the decision of national legislatures, executives and courts. As noted, the MoA is commonly invoked in situations in which there is normative flexibility in the relationship between individual freedoms and collective or societal rights and interests. ${ }^{81}$ As expressed in the Handyside case, the authorities 'direct and continuous contact with the vital forces of their countries' place them in a better position than the international judge to give an opinion on the exact content of the requirements of permissible limitations and to make the initial assessment of the reality of the pressing social need implied by the notion of 'necessity' in this context of the measures taken to meet such requirements. ${ }^{82}$ In matters of general policy, on which opinions within a democratic society may reasonably differ widely, the ECtHR considers that the role of the domestic policymaker should be given special weight. ${ }^{83}$ In such circumstances, the ECtHR has a 'duty to exercise a degree of restraint in its review of Convention compliance, since such review will lead it to assess a balance that has been struck by means of a democratic process within the

\footnotetext{
${ }^{78}$ Ibid.

${ }^{79}$ Ibid (citations omitted).

${ }^{80}$ See Lady Arden, 'Peaceful or Problematic? The Relationship between National Supreme Courts and Supranational Courts in Europe' (2010) 29 Yearbook of European Law 3.

${ }^{81}$ See Letsas, supra $n$ 00, 84-90 who describes this as the substantive use of the MoA.

${ }^{82}$ Handyside, supra n 00, para 48 (emphasis added).

${ }^{83}$ Maurice v. France [GC], A. 11810/03, para 117. A common situation of such differing opinions faced by the ECtHR has concerned the relationship between the State and religions, see Şahin v. Turkey [GC], para 109.
} 
society in question' ${ }^{84}$ For such respect for national decisions to be overborne there needs to be powerful considerations and reasoning based on the core moral principles or values of the human rights concerned. ${ }^{85}$

Thus national authorities are viewed as having stronger, and sometimes more direct, democratic, legitimation and being, in principle, better placed than an international court to evaluate local needs and conditions. ${ }^{86}$ However, the quality of the parliamentary and judicial review of the necessity of the measure in the respondent State is of particular importance to the operation and extent of the relevant MoA. ${ }^{87}$ Quality in this context is probably best understood as meaning substantive and credible discussion of the human rights issues rather than as having to achieve a particular qualitative standard ${ }^{88}$ In Animal Defenders International $v U K^{89}$ the ECtHR attached considerable weight to exacting and pertinent reviews, by both parliamentary and judicial bodies, of the complex regulatory regime governing political broadcasting in the UK and to their view that the general measure was necessary to prevent the distortion of crucial public interest debates and, thereby, the undermining of the democratic process. ${ }^{90}$ By contrast in Alajos Kiss $v$ Hungary ${ }^{91}$ the ECtHR observed that was no evidence that the Hungarian legislature has ever sought to weigh the competing interests or to assess the proportionality of the relevant restrictions on voting by persons under partial guardianship. Similarly in Dickson $v U K^{92}$ there was no evidence that when fixing the Policy on requests for artificial insemination by prisoners the Secretary of

${ }^{84}$ SAS v. France [GC], A.43835/11, para 154. Cf In Redfearn v UK, A. 47335/06, the ECtHR held by 4 to 3 that the inability of an employee dismissed for membership of the British National Party to bring a complaint of political discrimination violated Article 11 . The view of the dissenting judges was that this pressed the positive obligation too far. In a complex area of social and economic policy, 'it was pre-eminently for Parliament to decide what areas require special protection in the field of employment and the consequent scope of any exception created to the general rule', para 4.

${ }^{85}$ For example, Othman (Abu Qatada) v. UK, A. 8139/09, Merits, (2012) 55 EHRR 1, paras 266-67 concerned the approach to an issue of principle concerning a real risk of an extraterritorial violation of the right to a fair trial. See C. Michaelsen, 'The renaissance of non-refoulement? The Othman (Abu Qatada) decision of the ECtHR' (2012) 61 International and Comparative Law Quarterly 750.

${ }^{86}$ Greens and MT v UK, A. 60041/08, Merits, (2011) 53 EHRR 21, para 113.

${ }^{87}$ Animal Defenders International v. UK [GC], A. 48876/08 (2013), para 00.

${ }^{88}$ In (HS2 Action Alliance Ltd) $v$ The Secretary of State for Transport [2014] UKSC 3 the UK Supreme Court indicated that assessing parliamentary debates would raise constitutional issues in the light Article 9 of the Bill of Rights (1689), see paras 78-79, 200-211.

${ }^{89}$ Supra n 00.

${ }^{90}$ Ibid., para 00.

${ }^{91}$ Supra n 00, para 41.

${ }^{92}$ A. 44362/04) [GC], para 83 (4 December 2007). 
State had sought to weigh the relevant competing individual and public interests or assess the proportionality of the restriction. Further, since the Policy was not embodied in primary legislation, the various competing interests were never weighed, nor issues of proportionality ever assessed, by Parliament.

States will naturally be supportive of the concept of a MoA because it gives them more room for manoeuvre, that is, more scope for them to take decisions and for those decisions to be judged to be consistent with the ECHR. For example, the argument coming from the UK has been that the MoA is either not being applied, is being applied too narrowly, ${ }^{93}$ or is being applied inconsistently. ${ }^{94}$ The criticism is applied both to UK courts when they 'take into account' the ECHR jurisprudence under s. 2 of the UK's Human Rights Act 1998, and to the jurisprudence of the ECtHR itself. For example, the UK government's view has been that, in interpreting and applying Article 8, the domestic courts have placed too much weight on the family rights of foreign criminals. ${ }^{95}$ It has sought to redress the balance in the Immigration Rules by ensuring that they more fully reflect the compelling public interest in the maintenance of an effective immigration control in respect of those who have committed criminal offences. ${ }^{96}$ The UK government regards Parliament, before whom changes to the Immigration Rules are laid, as best placed to decide on difficult policy questions such as where the balance should be struck in relation to the deportation of foreign criminals. In changing the Rules it claimed that it would be respecting the jurisprudence of the ECtHR and reflecting the margin of appreciation that the Court afforded Member States in coming to such decisions. ${ }^{97}$ The ECtHR's approach to the MoA has been the focus of increasing criticism from the UK government in particular. The terms of that critique were

\footnotetext{
${ }^{93}$ See Lord Neuberger, 'The Incoming Tide: The Civil Law, The Common Law, Referees and Advocates' (suggesting that ECtHR might well benefit from developing the MoA to take greater account of practical differences which arise between Convention states and their implementation of high level principles) available at <http://www.judiciary.gov.uk/media/speeches/2010/mr-speech-euro-circuit-lecture-june2010>; Hale, supra n. 29, 542-3 who comments that the 'The evolutive approach to interpreting the Convention tends to lead to a narrowing of the margin of appreciation'. ${ }^{94}$ See Lord Dyson, supra n. 13; Arden LJ, supra n 00; Kratochvil, supra n 00.

${ }^{95}$ See D. Grieve, Attorney General: 'European Convention on Human Rights - current challenges?' Lincolns Inn, 24 October 2011, <http://www.attorneygeneral.gov.uk/NewsCentre/Speeches/Pages/AttorneyGeneralEuropean ConventiononHumanRights\%E2\%80\%93currentchallenges.aspx?>

${ }^{96}$ See particularly Immigration Rules, Part 13, Deportation, available at https://www.gov.uk/government/collections/immigration-rules.

${ }^{97}$ Grieve, supra n. 00 (emphasis added).
} 
partially reflected in the Brighton Declaration. ${ }^{98}$ The UK saw one way of strengthening the principle of subsidiarity as being for the ECtHR to afford Member States a wide MoA where national parliaments have implemented ECHR rights and where national courts have properly assessed the compatibility of that implementation with the ECHR.

The democratic legitimation argument can only be pushed so far though. Obviously, as an international court, the ECtHR does not have the same kind of democratic legitimation that national Parliaments, national governments and national courts do. ${ }^{99}$ However, it is based on a Treaty that 47 States have consented to and that the Treaty clearly provides for the binding legal status of the ECtHR's judgments. ${ }^{100}$ There is also a degree of democratic legitimacy stemming from the election of judges by the Parliamentary Assembly of the Council of Europe ${ }^{101}$ Moreover, history demonstrates that European democracies have been responsible for significant human rights abuses, including those against minorities such as the Roma. $^{102}$

\section{European human rights standards - minimal, uniform or harmonised}

If the ECtHR is perceived as an 'international Court', rather than a European Constitutional or European Supreme Court, then affording States a MoA is consistent with the idea that the ECtHR's function is not to decree uniformity wherever there are national differences, but to ensure that minimum, fundamental values are respected. ${ }^{103}$ A previous President of the

\footnotetext{
${ }^{98}$ See supra n. 00.

${ }^{99}$ See L. Hoffmann, 'The Universality of Human Rights' (2009) 125 Law Quarterly Review 416; J. Sumption, 'The Limits of Law' 20 November 2013, available at http://supremecourt.uk/docs/speech-131120.pdf. For a reply to Hoffman see R. Spano, 'Universality or Diversity of Human Rights? Strasbourg in the Age of Subsidiarity' (2014) 14 Human Rights Law Review 487.

${ }^{100}$ See J.P. Costa, On the Legitimacy of the European Court of Human Rights' Judgments, (2011) 7 European Constitutional Law Review 173; M. O'Boyle, 'The Future of the ECtHR' (2011) 12 German Law Journal 1862; A. Follesdal, 'Much Ado About Nothing? International Judicial Review of Human Rights in Well Functioning Democracies' in A. Follesdal, J. Schaffer and G. Ulfstein (eds)?, The Legitimacy of International Human Rights Regimes (Cambridge, CUP, 2014) 272.

${ }^{101}$ See Harris et al, supra n 00, 107-9.

${ }^{102}$ See D. H. And Others v. Czech Republic, A. 57325/00, para 182.

${ }^{103}$ See Mahoney, supra n 00, at 369. On comparable issues in an EU context see N. Nic Shuibhne, 'Margins of Appreciation: National Values, fundamental rights and the EC Free Movement Law' (2009) European Law Review 230; J. Gerards, 'Pluralism, Deference and the Margin of Appreciation Doctrine' (2011) 17 European Law Journal 80; M. Fischera and
} 
ECtHR has commented that the MoA, 'is a clear expression of the fact that the Convention does not command or even aspire to strict uniformity throughout Europe in the protection of human rights... The states parties to the Convention are required to secure all Convention rights within their domestic systems, but this does not imply wholesale standardisation of national institutions, procedures and practices. ${ }^{104}$

It is also critically important to understand that the MoA is used by the ECtHR to determine whether or not it considers that there is a violation of the ECHR. That the ECtHR has considered that a particular issue falls within the MoA does not preclude the national authorities, either legislative, executive or judicial, from considering that the ECHR should be interpreted at a level above the ECtHR's minimum. Thus in Pretty $v K^{105}$ in 2002 the ECtHR held that UK's general prohibition on assisted suicide fell within its MoA. In Nicklinson and Others v. Ministry of Justice and Others ${ }^{106}$ in 2014 the UK Supreme Court held that the question of compatibly was therefore a domestic question for the UK courts to decide. The majority of the SC considered that the general ban was incompatible with Article 8. However, it must be acknowledged that a finding of no violation based on the MoA may lead to a levelling down of national protections. ${ }^{107}$

\section{The Role of Consensus in Determining the Margin of Appreciation}

In determining the MoA the ECtHR may, if appropriate, have regard to any consensus and common values emerging from the state practices of the parties to the ECHR. ${ }^{108}$ It makes increasing use of the comparative method ${ }^{109}$ to indicate the degree of any European

E. Herlin-Karnell, 'The Margin of Appreciation Test and Balancing in the Areas of Freedom, Security and Justice' (2014) 19 European Public Law 759.

${ }^{104}$ Costa, ibid, at 180 (emphases in original). The obvious contrast is with EU law which operates in a manner to produce a much higher level of legal uniformity, for example, via the operation of EU Regulations and Directives.

105 A. 2346/02, (2002) 35 E.H.R.R. 1.

106 [2014] UKSC 38.

107 See E. Brems, 'Human Rights: Minimum and Maximum Perspectives' (2009) 9 Human Rights Law Review 349; Paczolay, infra n 00.

${ }^{108}$ Bayatyan v. Armenia [GC], A. 23459/03, para 122, ECHR 2011 (concerning conscientious objection to military service); Legg, supra n 00, 103-44. Reliance on consensus has also been a feature of the US Supreme Court's jurisprudence, see K. Dzehtsiarou and C. O'Mahony, 'Evolutive Interpretation of Rights Provisions: A Comparison of the EurCourtHR and the U.S. Supreme Court' (2013) 44 Columbia Human Rights L. Rev. 309.

${ }^{109}$ See e.g. Stübing v Germany, A. 43547/08, paras 28-30 (on criminalisation of consensual sexual acts between adult siblings). See J.A. Roffee, 'No Consensus on Incest: 
consensus on a particular issue. ${ }^{110}$ Normally a strong consensus will narrow the margin of appreciation and vice versa. ${ }^{111}$ In Schalk and Kopf $v$. Austria ${ }^{112}$ the ECtHR relied on the idea of the MoA and the absence of consensus to deny the existence of an ECHR right to samesex marriage. It considered that there was a complete lack of consensus about same-sex marriage in Europe due to the fact that 'marriage has deep-rooted social and cultural connotations which may differ largely from one society to another.' ${ }^{113}$ In that context, the question whether or not to allow same-sex marriage was left to regulation by the national law of the states. ${ }^{114}$ This was a policy field where national authorities were better placed 'to assess and respond to the needs of society.' ${ }^{115}$ A former President of the ECtHR has explained that it looked for consensus before it narrowed the margin. He saw this as a safeguard 'to prevent any rapid and arbitrary development of the Convention rights' ${ }^{116} \mathrm{He}$ has also argued that the, 'frequent anchoring of the Court's development of the case-law to perceivable developments at national or international level, has been a further feature of the Court's case-law with a view to ensuring that legal developments keep pace with, but do not leap ahead of, societal changes within Europe'. ${ }^{117}$

Consensus is significant in terms of weighting but it is not necessarily decisive or determinative. ${ }^{118}$ Even a strong consensus amongst a substantial majority of the Contracting

Criminalisation and Compatibility With the ECHR' (2014) 14 Human Rights Law Review 541. The Court now has a research department which is designed to undertake comparative analysis following the request of the Judge Rapporteur. See P. Mahoney, 'The Comparative Method in Judgments of the EurCourtHR: Reference Back to National Law' in G. Canivet, M. Andenas and D. Fairgrieve (eds), Comparative Law Before the Courts ( 2004) 135-50; K. Dzehtsiarou, 'Comparative Law in the Reasoning of the ECtHR' (2010)(10) UCD Law Review 109, available at <http://epubs.surrey.ac.uk/186004/>; K. Dzehtsiarou and V. Lukashevich, 'Informed Decision-Making: The Comparative Endeavours of the Strasbourg Court' (2012) Netherlands Quarterly of Human Rights 272.

${ }^{110}$ See Discussion Paper, 'The Role of Consensus in the System of the ECHR' in Dialogue Between Judges, ECtHR, Strasbourg, (2008) available at http://www.echr.coe.int/Documents/Dialogue_2008_ENG.pdf, at 11-18.

${ }^{111}$ Stübing v Germany, supra n 00, paras 58-61; A, B and C v Ireland, [GC], A.25579/05, (2011) 53 EHRR 13, paras 229-41. See K. Dzehtsiarou, 'Does Consensus Matter? Legitimacy of European Consensus in the Case Law of the European Court of Human Rights' (2011)

Public Law 534; Spielmann, supra n. 00, 18-25.

${ }^{112}$ A. 30141/04 (24 June 2010).

113 Ibid., para 62.

114 Ibid., para 61.

115 Ibid.

116 See Bratza, supra n 00, HC 873-iii, Q 140.

${ }^{117}$ Bratza, supra n 00, at 124.

${ }^{118}$ Hirst v. UK (No. 2) [GC], A. 74025/01, para 81. 
States may not decisively narrow the broad margin of appreciation of the State if the broader context of the issue remains one where there is no European consensus ${ }^{119}$ or where 'special historical or political considerations exist which render a more restrictive practice necessary'. ${ }^{120}$ Where there is no consensus within the Member States of the Council of Europe, either as to the relative importance of the interest at stake or as to the best means of protecting it, particularly where the case raises sensitive moral or ethical issues, the MoA will be wider. ${ }^{121}$ If an emerging consensus is not based on settled and long-standing principles established in the law of the member States but rather reflects a stage of development within a particularly dynamic field of law, this does not decisively narrow the margin of appreciation of the State'. ${ }^{122}$ An important aspect of looking for the consensus is that the jurisprudence on particular controversial issues may take significant periods of time to be established. That gives States time to reflect on comparative social, economic and scientific developments both within and across States. For example, the ECtHR's jurisprudence on transsexuals changed significantly but over a 16 year period. ${ }^{123}$ In fact in that particular instance the European consensus had not changed much in that period but the ECtHR considered that there was a 'clear and uncontested evidence' of a 'continuing international trend' in favour of increased social acceptance of transsexuals and of legal recognition of the new sexual identity of post-operative transsexuals. The evidence cited came from Singapore, Canada, South Africa, Israel, Australia, New Zealand and states within the US. ${ }^{124}$

${ }^{119}$ This was so in $A, B$ and $C$. v Ireland [GC], supra n 00, as there remained no European consensus on the scientific and legal definition of the beginning of life, para 237. For critiques see S. Krishnan, 'What's the Consensus: The Grand Chamber's decision on abortion in A, B and C v Ireland' (2010) EHRLR 200; C. Ryan, 'The margin of appreciation in A, B and $\mathrm{C} v$ Ireland: a disproportionate response to the violation of women's reproductive freedom' (2014) UCL Journal of Law and Jurisprudence 237.

${ }^{120}$ Republican Party of Russia v Russia, A. 12976/07, para 126.

${ }^{121}$ S.H. v Austria, [GC], A. 57813/00, (2011) 52 EHRR 6 (concerning the use donated sperm or ova for in vitro fertilization ('IVF'); Hämäläinen v. Finland [GC], A.37359/09, 16 July 2014 (concerning a requirement of change of marital status for a transsexual to be recognised as a woman).

${ }^{122}$ Ibid. para 96. The minority disagreed with this additional reference step 'of conferring $a$ new dimension on the European consensus and applying a particularly low threshold to it, thus potentially extending the States' margin of appreciation beyond limits.'

${ }^{123}$ From Rees v UK, A. 9532/81 (1986) to Christine Goodwin v UK, A. 28957/95 (2002).

${ }^{124}$ See R. Sandland, 'Crossing and Not Crossing: Gender, Sexuality and Melancholy in the European Court of Human Rights' (2003) 11 Feminist Legal Studies 191. 
Generally the working assumption of the ECtHR has been that human rights standards incrementally and progressively increase, ${ }^{125}$ and so the MoA only tends to narrow over time. Thus consensus is normally relied upon to expand the scope of rights and restrict the scope of limitations. However, legal and social experimentation is possible within limits. ${ }^{126}$ It is clear that it is open to States to impose new restrictions on rights and these may fall within the MoA even if other States have not imposed them. ${ }^{127}$ A striking illustration is the ban on the wearing in public places of clothing that is designed to conceal the face (the so-called Burqaban). ${ }^{128}$ Of the 47 Member States of the Council of Europe, only France and Belgium had actually imposed such bans. Nonetheless, in SAS v. France ${ }^{129}$ in 2014 the ECtHR considered that there was no European consensus as to whether or not there should be a blanket ban on the wearing of the full-face veil in public places. It admitted that, from a strictly normative standpoint, France was very much in a minority position in Europe. However, the question of the wearing of the full-face veil in public was or had been a subject of debate in a number of European States. In some it had been decided not to opt for a blanket ban. In others, such a ban was still being considered. In all likelihood, the question of the wearing of the full-face veil in public was simply not an issue at all in a certain number of member States, where this practice was uncommon. ${ }^{130}$ The ECtHR held that having regard in particular to the breadth of the margin of appreciation accorded to France, the ban could can be regarded as proportionate to the aim pursued, namely the preservation of the conditions of 'living together' as an element of the 'protection of the rights and freedoms of others'. ${ }^{131}$

${ }^{125}$ See Demir and Baykara v. Turkey, No. 34503/97, para 146; Vereinigung Bildender Künstler v. Austria, A. 68354/01 (satire was a form of artistic expression and social comment which, by exaggerating and distorting reality, was intentionally provocative. Accordingly, any interference with an artist's right to such expression had to be examined with particular care).

${ }^{126}$ It is notable that in $S$ and Marper v. UK [GC], A. 30562/04 and 30566/04, 4 December 2008, para 112 the ECtHR considered that 'any State claiming a pioneer role in the development of new technologies bears special responsibility for striking the right balance [between public and private interests) in this regard'.

${ }^{127}$ See P. Mahoney, 'Marvellous Richness of Diversity or Invidious Cultural Relativism?' (1998) 19 Human Rights Law Journal 4 (on social experimentation).

${ }^{128}$ See A. Ferrari and S. Pastorellivi, The Burqa Affair Across Europe (Farnham: Ashgate, 2013).

129 [GC], A.43835/11, paras 106-59 (1 July 2014).

${ }^{130}$ Ibid., para 156.

${ }^{131}$ Ibid., para 157. See J. Adenitire, 'Has the European Court of Human Rights recognised a legal right to glance at a smile?' (2014) 131 Law Quarterly Review 43. 
There are two further factors in support of a consensus analysis. The first is an instrumental one. The ECHR is posited on the idea of shared cultural values based on a 'common heritage of political traditions, ideals, freedom and the rule of law'. ${ }^{132}$ If the interpretation of the ECHR by the ECtHR enjoys widespread underlying support in other states across the Council of Europe, this obviously makes ultimate acceptance and implementation of the ECtHR's evolutive interpretation by national legislatures, executives and judiciaries significantly more likely. ${ }^{133}$ The search for consensus reflects a judicial philosophy of establishing some basic, if increasingly sophisticated, minimum standards rather than one of unifying or harmonising standards. ${ }^{134}$ In short, the search for consensus puts a sensible limit on judicial creativity. ${ }^{135}$ The second is a normative one. Although judgments of the ECtHR are technically binding only on the State part concerned, in effect the jurisprudence has an erga omnes effect. The ECHR has been incorporated in some manner and form in all 47 States parties to the ECHR and they are urged to take account of the ECHR jurisprudence and to draw the necessary implications with respect to their own laws and practice. ${ }^{136}$ Much of the comparative success of the ECHR ultimately depends on the co-operation of the national courts. The Committee of Ministers of the Council of Europe

${ }^{132}$ Preamble to ECHR. See I.R. del Moral, 'The Increasingly Marginal Appreciation of the Margin-of-Appreciation Doctrine' (2006) 7 German Law Journal. 611.

${ }^{133}$ See Dzehtsiarou, supra n 00, at 1745. On implementation difficulties see B. Cali and A. Koch, 'Foxes Guarding the Foxes? The Peer Review of the Human Rights Judgments by the Committee of Ministers of the Council of Europe' (2014) 14 Human Rights Law Review 301; A. Huneeus, 'Courts Resisting Courts: Lessons From the Inter American Court's Struggle to Enforce Human Rights' (2011) 44 Cornell ILJ 493.

${ }^{134}$ See Vo v. France, A. 53924/00, para 22 [GC]; C. Rozakis, 'Is the Case Law of the ECtHR a Procrustean Bed?' (2009 2) UCL Law Review 51 who observes that as European states have increasingly been in agreement on common standards of protection of human rights in many areas, the MoA is shrinking, for the benefit of more harmonised protection around Europe, at 65 .

${ }^{135}$ See P. Mahoney, 'Judicial Activism and Self-Restraint in the European Court of Human Rights: Two Sides of the Same Coin' (1990) 11 Human Rights Law Journal 57.

${ }^{136}$ See Brighton Declaration, supra n 00; s. 2 Human Rights Act (1998) (UK); A. Kovler and O. Chernishova, 'The June 2013 Resolution 21 of the Russian Supreme Court - A Move Towards Implementation of the Judgments of the ECtHR' (2013) 33 Human Rights Law Journal 263; P. Popelier, C. Van de Heyning and P. Van Nuffel (eds), Human Rights Protection In The European Legal Order: The Interaction Between The European And The National Courts (Cambridge: Intersentia, 2011); H. Keller and A. Stone-Sweet, A Europe of Rights (Oxford: OUP, 2008). 
and the ECtHR increasingly stress that implementing ECtHR's judgments is a shared judicial responsibility. ${ }^{137}$

A detailed analysis of the ECtHR's practice with respect to consensus published in 2013 concluded that, 'consensus analysis is a sound and constructive idea' ${ }^{138}$ However, even when judges accept the concept of looking for consensus in determining the MoA, there have been cases where have been significant and often very critical dissents on how it should be assessed. In Evans $v U K^{139}$ there was a four-judge dissent describing a decision based on a wide margin of appreciation due to the absence of a consensus as simplistic and mechanical. ${ }^{140}$ In Chapman $v U K^{141}$ a seven-judge dissent rejected the majority's assertion that the consensus was not sufficiently concrete and their conclusion that the complexity of the competing interests rendered the Court's role a strictly supervisory one. In X v. Austria ${ }^{142}$ there was a strong seven-judge dissent on the basis that, as the States in question were sharply divided, therefore there was no consensus. In Animal Defenders International v. UK ${ }^{143}$ there was an eight-judge dissent, essentially differing on the application of what they all agreed was a narrow MoA, regarding restrictions on expression on matters of public interest. The majority and the minority differed in their assessment of whether there was a European

${ }^{137}$ See 'Implementation of the Judgments of the ECtHR: A Shared Judicial Responsibility' ECtHR, Dialogue Between Judges 2014, available at http://www.echr.coe.int/Documents/Dialogue_2014_ENG.pdf.

${ }^{138}$ See L. Wildhaber, A. Hjartarson and S. Donnelly, 'No Consensus on Consensus? The Practice of the European Court of Human Rights' 33 (2013) Human Rights Law Journal 248 at 262. Similarly, Kratochvil, supra n 00, at 357 (The justification of the doctrine has a sound basis and the margin of appreciation has a role in the decision making of an international tribunal). For the argument that consensus fails to provide epistemic justification for the belief that human rights are universal see E-J K Kim, 'Justifying Human Rights: Does Consensus Matter? (2012) 13 Human Rights Review 261.

139 [GC], A. 6339/05.

${ }^{140}$ It also stated that the ECtHR 'should not use the margin of appreciation principle as a merely pragmatic substitute for a thought-out approach to the problem of proper scope of review'

${ }^{141}$ A. $27238 / 95$ [GC].

142 [GC], A. 19010/07, (2013) 57 EHRR 14 (concerning second-parent adoption). A number of considerations relating to comparative and international law led the minority to the conclusion that there had been no violations of Article 14 taken in conjunction with Article 8 ECHR.

${ }^{143}$ [GC] A. 48876/08, 22 April 2013. 
consensus. ${ }^{144}$ In Biao v. Denmark ${ }^{145}$ there was a 4:3 decision differing fundamentally on the application of the MoA.

\section{Critiques of the Margin of Appreciation}

The MoA has its critics both inside ${ }^{146}$ - one ECtHR Judge, Martens, famously described references to the MoA as being 'unnecessary circumlocutions' which were 'as wrong in principle as it is pointless in practice', ${ }^{147}$ - and outside of the ECtHR. ${ }^{148}$ There are critics of the concept's existence and of its use by the ECtHR. The fundamental critique is that the MoA erodes normative standards by encouraging their non-uniform, subjectivist or relativist applications, the consequences of which are inconsistent with the universality of human rights ${ }^{149}$ and the concept of the rule of law. ${ }^{150}$ The lack of clarity inherent in the MoA makes for a lack of predictability in judicial decision making which is inconsistent with the principle of legal certainty. ${ }^{151}$ The search for consensus is thus contrary to basic rule of law

${ }^{144}$ Given the very significant and controversial legislative reform that would have to follow, it is open to question whether a bare or small majority decision by the ECtHR should be sufficient. Quaere whether a finding of violation should need, for example, 12 votes out of 17 in the Grand Chamber? Murray, supra n 00, observes that there was a convention in the ECJ that established jurisprudence would not be overruled on the basis of a bare or narrow majority even of the full court.

${ }^{145}$ A. 38590/10 (25 March 2014), (to rules concerning family reunification). An application to refer the case to the GC was accepted.

${ }^{146}$ See MacDonald, supra n 00; Z. v. Finland, A. 220009/93, dissenting opinion of judge De Meyer (concept should be banished); Engeland and Hanseid v. Norway, A. 34438/04, concurring opinion of Judge Rozakis (concept often used automatically and unnecessarily); C. Rozakis, 'Through the Looking Glass: An Insider's View of the Margin of Appreciation' in Mélanges en l'honneur de Jean-Paul Costa (.....: Dalloz, 2011)..

${ }^{147} Z$ v. Finland, A. 22009/93, dissenting opinion.

${ }^{148}$ See G. Letsas, A Theory of Interpretation of the ECHR (Oxford: OUP, 2010); E. Benvenisti, 'Margin of Appreciation, Consensus, and Universal Standards' (1999) 31 Journal of International Law and Politics 843; A. Lester, 'Universality Versus Subsidiarity: a Reply' (1998) European Human Rights Law Review 73; Arai-Takahashi, supra n. 00 (2013); Kratochvil supra n 00; Murray, (Chief Justice of Ireland) 'Consensus: Concordance, or Hegemony of the Majority?' in Dialogue Between Judges, supra n 00; T. H. Jones, 'The Devaluation of Human Rights Under the European Convention' (1995) Public Law 430; G. Itzcovich, 'One, None and a Hundred Thousand Margins of Appreciation: The Lautsi Case' (2013) 13 Human Rights Law Review 287.

${ }^{149}$ See E. Brems, Human Rights: Universality and Diversity (The Hague: Kluwer, 2001) 357421.

${ }^{150}$ See Shany, supra n 00, at 912.

${ }^{151}$ See J. A. Brauch, 'The Dangerous Search for an Elusive Consensus: What the Supreme Court Should Learn from the EurCourtHR' (2009) 52 Howard Law Journal 277. 
requirements because it creates vague standards that defeat predictability. ${ }^{152}$ The wide MoA afforded by the ECtHR during emergencies has been criticized. Gross and Ni Aolain, for example, argue that ECtHR should afford the narrowest of margins to national governments in a derogation context, especially when the emergency is an entrenched one. ${ }^{153}$ This is partly based on the view that the ECtHR should act as the ultimate protector of human rights. ${ }^{154}$ In any event, although Gross and Ni Aolain argue that a wide MoA is misguided, they do not assert that the margin should be done away with. Rather, a certain MoA ought to be given to governments to deal with exigencies and acute crises. It should though be kept to bare minimum. ${ }^{155}$

There are accompanying methodological criticisms of both the role of consensus on determining the MoA and the widely acknowledged absence of a clear and consistent methodology underlying the search for consensus ${ }^{156}$ - which States?, how many?, what practice?, for how long?, what of the practice of non-Parties to ECHR?, ${ }^{157}$ what weight is given to ratified and unratified treaties inside the Council of Europe and outside of it? ${ }^{158}$ One problematic issue for the future will be whether, once the EU becomes a party to ECHR, whether EU rules can be regarded as evidence of consensus? If so, would this create a presumption of their compliance with the ECHR? There has also been criticism of the formulation of the issue or question on which consensus does or does not attach. The answer can vary depending on the formulation. In Sahin v Turkey ${ }^{159}$ the narrow factual issue was the regulation of religious clothing in a university. There was no uniform European conception of the significance of religion in society or the wearing of religious symbols in educational institutions but there was a virtual consensus on whether adult women in universities can wear religious clothing. The ECtHR chose the first two formulations of the consensus issue. In Stec $v U K^{160}$ the ECtHR applied a wide margin on the basis that the case concerned social policy, rather than a narrow margin on the basis that the case concerned sex discrimination. The different outcomes of the Chamber and the GC in Lautsi v. Italy, concerning the display

\footnotetext{
152 Ibid.

${ }^{153}$ See O. Gross and F. Ni Aolain, 'From Discretion to Scrutiny...' (2001) 23 Human Rights Quarterly 625.

${ }^{154} \mathrm{Id} ., 641$.

${ }^{155}$ Id., 648.

${ }^{156}$ See Wildhaber et al, supra n 00; Dzehtsiarou and O’Mahony, supra n. 00.

${ }^{157}$ See the wider range of practice considered in Christine Goodwin v. UK, supra n. 00.

${ }^{158}$ See Demir v. Turkey, A. 34503/97.

${ }^{159}$ Supra n 00.

${ }^{160}$ [GC], A. 65731/01, para 66.
} 
of crucifixes in classrooms, can also be explained by how the issue was framed. ${ }^{161}$ Finally, the search for and identification of consensus risks imposing the majority view on a minority, even a substantial minority, of states.

Others regard the MoA as acceptable in principle and an appropriate concept in the subsidiary context in which it is used, but criticise its use or the approach to determining consensus in particular cases. Lord Hoffmann described the doctrine of the 'margin of appreciation' as an 'unfortunate Gallicism' by which Member States were allowed a certain latitude to differ in their application of the same abstract right. ${ }^{162} \mathrm{He}$ supported the recognition of the MoA but was critical that there was no consistency in its application. Moreover, he did not think that there was a proper understanding of the principle upon which it should be based. ${ }^{163}$ In practice, the ECtHR had not taken the doctrine of the MoA nearly far enough. It had been unable to resist the temptation to aggrandise its jurisdiction and to impose uniform rules on Member States. For him the ECtHR considered itself the equivalent of the Supreme Court of the United States, laying down a federal law of Europe. ${ }^{164}$ However, he considered that the ECtHR lacked constitutional legitimacy for such a role. ${ }^{165}$ Lord Sumption, after his selection to be a UK Supreme Court Justice, similarly criticised the ECtHR for treating the ECHR 'not just as a safeguard against arbitrary and despotic exercises of state power, but as a template for most aspects of human life'. ${ }^{166}$

A final criticism of some uses of the MoA by the ECtHR is that reference to it is just a redundant and unnecessary rhetorical justification or conclusory label for an end result. ${ }^{167}$ This is particularly so where the ECtHR has effectively engaged in its own review of the

${ }^{161}$ See D. McGoldrick, 'Religion in the European Public Square and in European Public Life - Crucifixes in the Classroom?' (2011) 11 Human Rights Law Review 451; Itzcovich, supra n 00; M. Lugato, 'The "Margin of Appreciation" and Freedom of Religion: Between Treaty Interpretation and Subsidiarity' (2013) 52 Catholic Legal Studies 49.

${ }^{162}$ Lord Hoffman, supra n. 00, paras 21, 44.

${ }^{163}$ Id., para 27.

$164 \mathrm{Id}$.

${ }^{165}$ Id., para 38.

${ }^{166}$ J. Sumption, 'Judicial and Political Decision-Making: The Uncertain Boundary' available at <http://www.legalweek.com/digital_assets/3704/MANNLECTURE_final.pdf> For a critical reply see S. Sedley, 'Judicial Politics' (23 Feb 2012) 34(4) London Review of Books. Lord Sumption has continued to criticize the ECtHR for becoming the "the international flagbearer for judge-made fundamental law extending well beyond the text which it is charged with applying', 'The Limits of Law' 27th Sultan Azlan Shah Lecture, 20 November 2013, available at https://www.supremecourt.uk/docs/speech-131120.pdf.

${ }^{167}$ See Kratochvil, supra n 00; Letsas, supra n 00, at 86-90. 
merits by applying a strict standard of proportionality. If it judges the measures proportionate it simply adds that the State is within its MoA; if not it simply adds that it has exceeded its MoA. ${ }^{168}$

\section{[NEED TO CONSIDER WHAT IF ANYTHING IN SECTIOSN 6 AND 7 I NEED TO KEEP BY WAY OF CROSS REFERENCE?]}

\section{The Non-Use of the Margin of Appreciation by the Human Rights Committee}

As noted, the ECHR's MoA jurisprudence began in the context of derogations. The HRC, while acknowledging the sovereign right of a State to declare a state of emergency, has asserted a measure of international supervision over that national determination. ${ }^{169}$ That starting point closely parallels that of the ECtHR. ${ }^{170}$ However, while a wide MoA on both the existence of a state of emergency and the appropriate responses to it is central in ECHR jurisprudence on Article $15 \mathrm{ECHR},{ }^{171}$ the HRC has maintained that it does not use a MoA approach in assessing derogations. This is so even though express reference to the MoA doctrine was made during drafting of the ICCPR at the UN's Third Committee in $1963 .{ }^{172}$ It is notable that the HRC's General Comment 29 (2001) on States of Emergency ${ }^{173}$ made no reference to any MoA.

Apart from one early case in $1982,{ }^{174}$ the HRC has not only studiously avoided the language of the MoA, it has expressly disowned it. ${ }^{175}$ Within the context of Article 27 (minority rights) the HRC has stated that while a State may understandably wish to encourage development or allow economic activity by enterprises,

'The scope of its freedom to do so is not to be assessed by reference to a margin of appreciation, but by reference to the obligations it has undertaken in article 27.' 176

\footnotetext{
${ }^{168}$ See Arai- Takahashi, supra n. 00, 232-5.

${ }^{169}$ Ref? ....Cf other contexts of doing this in the Covenant?? Maroufidou etc?

${ }^{170} \mathrm{Cf}$ supra $\mathrm{n} 00$ [A. v UK].

${ }^{171}$ See Brannigan and McBride v UK, A. Nos. 14553/89, 14554/89, 17 EHRR (????) 539;

Harris et al, supra n 00, 00-00.

${ }^{172}$ See UN Doc A/5655, para 49.

${ }^{173}$ UN Doc UN Doc. CCPR/C/21/Rev.1/Add.11 (31 August 2001),

174 The Hertzberg case referred to below.

${ }^{175}$ See P.R. Ghandhi, The HRC and the Right of Individual Communication (Aldershot: Ashgate, 1998) 311-4.

${ }^{176}$ Länsman et al. v. Finland, Cmn No. 511/1992, para 9.4 (emphasis added).
} 
This approach could have been limited to articles which do not have express limitations clauses. However, in the HRC's extensive jurisprudence on rights with express limitations the HRC decides cases with reference to the text of the ICCPR, but never by reference to any concept of a MoA. ${ }^{177}$ It emphasized this point in General Comment 34 on 'Article 19: Freedoms of opinion and expression',

The Committee reserves to itself an assessment of whether, in a given situation, there may have been circumstances which made a restriction of freedom of expression necessary. ${ }^{178}$ In this regard, the Committee recalls that the scope of this freedom is not to be assessed by reference to a "margin of appreciation" 179 and in order for the Committee to carry out this function, a State party, in any given case, must demonstrate in specific fashion the precise nature of the threat to any of the enumerated grounds listed in paragraph 3 that has caused it to restrict freedom of expression. $^{180}$

\section{Explanations for the Non-Use of the Margin of Appreciation by the Human Rights Committee}

There are a range of possible explanations.

\section{A. Protecting the universality of human rights}

The simplest explanation is that which sees in the MoA as a threat to the universality of human rights. ${ }^{181}$ As such, the threat should not be supported or encouraged. The risk of expressly acknowledging the existence of a MoA would be that States would inevitably seek support from it to validate a diminishing and variable normative content for international human rights. Admitting a MoA doctrine 'might prompt some States to rely on arguments of

${ }^{177}$ See generally Joseph et al, The ICCPR - Cases, Materials and Commentary, $3^{\text {rd }}$ edn (Oxford: OUP, 2013).

${ }^{178}$ Citing Sohn v. Republic of Korea, Cmn No. 518/1992.

${ }^{179}$ Citing Länsman, supra n 00.

${ }^{180}$ GC 34, para 16, citing Sohn, supra n 00 and Shin v. Republic of Korea, Cmn No. 926/2000.

${ }^{181} \mathrm{Cf}$ Arai-Takashi, supra n 00, has suggested that the UN Human Rights Council avoids use of MoA because of inconsistency with very idea of human rights, at ix. 
"cultural relativism", however ill-defined or inappropriate in the circumstances of a given case, or seek to justify serious human rights abuses. ${ }^{, 182}$ Whilst the risk is comprehensible the explanation depends on a rather simplistic and unreal conception of universality. The requirements under Article 2 to respect and ensure ICCPR rights are unqualified and of immediate effect. A failure to comply with this obligation cannot be justified by reference to political, social, cultural or economic considerations within the State. ${ }^{183}$ States parties should ensure that traditional, historical, religious or cultural attitudes are not used to justify violations of the rights of women right to equality before the law and to equal enjoyment of all Covenant rights. ${ }^{184}$ However, the criticial prior question is to determine the scope of the obligations under the substantive ICCPR rights. Although human rights are universal in the sense of imposing some minimum fundamental standards, universalism does not operate by means of uniform, harmonised rules which cannot be varied. ${ }^{185}$ This is true with respect both to the protection of rights and remedies.

\section{B. Anti-Eurocentrism}

A second explanation of non-use of MoA by HRC lies in the MoA's association with the ECHR system. A number of members of the HRC have also been members of the ECtHR or the European Commission on Human Rights. ${ }^{186}$ Particularly in its first decades the HRC did not want to appear to be Eurocentric in approach. That may be a sensitive political explanation for the early practice of the HRC but as it matured it had to determine the jurisprudential approach that was appropriate in principle, irrespective of where it has been used or was associated with. Of the 47 states parties to ECHR 4? are also parties to the ICCPR. Many of them have accepted OP1 and argued before the HRC that decisions of the ECtHR or at least its jurisprudential approach, based on an application of the MoA (or a

\footnotetext{
${ }^{182}$ See Schmidt, supra n 00, at 657.

183 GC 31, supra n 00, para 14.

${ }^{184}$ General Comment 28, Article 3 - The equality of rights between men and women, para 5. ${ }^{185}$ See P. Contreras, 'National Discretion and International Deference in the Restriction of Human Rights: A Comparison Between the Jurisprudence of the European and the InterAmerican Court of Human Rights' (2012) 11 Northwestern Journal of International Human Rights Law 28.

${ }^{186}$ For example, Opsahl, Ermacora, Vincent-Evans, Palm.
} 
margin of discretion), ${ }^{187}$ should be followed. ${ }^{188}$ For example, in B.W.M.Z. v. Netherlands ${ }^{189}$ the State submitted observations on admissibility and merits. It recalled the decision of inadmissibility adopted by the ECtHR and asked the HRC, for reasons of legal certainty, to take a similar approach, that was, to declare that the communication was inadmissible or that it did not constitute a violation of the Covenant. Otherwise, the State would be confronted with contradictory rulings by two international supervisory bodies on an identical issue. ${ }^{190}$ In other cases States have argued for a MoA even when there is no equivalent ECHR jurisprudence. ${ }^{191}$ Thus in M.B. v. Czech Republic ${ }^{192}$ the State argued that the legislator possessed a MoA within which it could lay down citizenship requirements on the part of applicants requesting the surrender of property.

\section{Misunderstanding of the $M o A$}

A third possible explanation for non-use of the MoA by the HRC is that there often appears to be widespread misunderstanding of the MoA and how it operates. Figure 1 seeks to illustrate this faulty understanding.

${ }^{187}$ See Atasoy et al v. Turkey, Cmn Nos. 1853/2008 and 1854/2008, para 7.6; Sechremelis v. Greece, Cmn No. 1507/2006, para 8.2; Albareda et al v. Uruguay, Cmn Nos. 1637/2007, 1757/2008 and 1765/2008, para 4.2; Brychta v. The Czech Republic, Cmn No. 1618/2007, para 4.2.

${ }^{188}$ See Brandsma v. The Netherlands, Cmn No. 977/2001, paras 4.2-4.3; Crippa, et al v. France, Cmn No. 993-995/2001, pr. 4.10; Vojnovic v. Croatia, Cmn No. 1510/2006, para 4.10; Althammer et al. v. Austria, Cmn No. 803/1998, para 4.6. See also the cases discussed in Part 00 below.

${ }^{189}$ Cmn No. 1788/2008, para 4.1. The communication was inadmissible for non exhaustion of domestic remedies or non substantiation of claims.

${ }^{190}$ Some States have avoided this possibility by reservations to prevent reconsideration of cases. See C. Phuong, 'The Relationship Between the European Court of Human Rights and the Human Rights Committee: Has the 'Same Matter' Already Been 'Examined'?' (2007) 7 Human Rights Law Review 385; Gerards, infra n 00.

${ }^{191}$ See Novotny v. Czech Republic, Cmn No. 1778/2008, para 4.6.

192 Cmn No. 1849/2008, para 4.16. The communication was declared inadmissible because the delay in submission was so unreasonable and excessive as to amount to an abuse of the right of submission. 


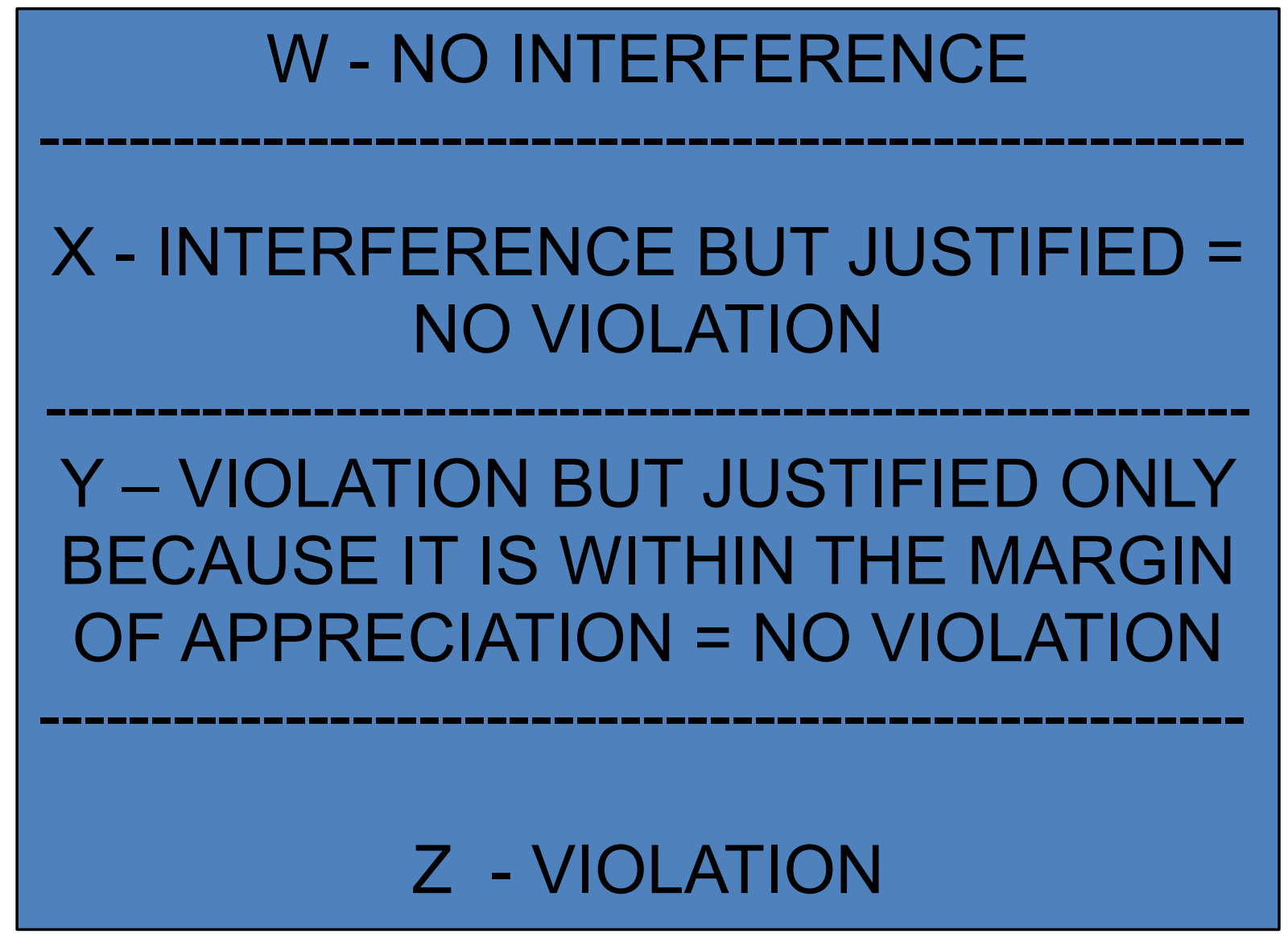

At point $\mathrm{W}$ there is no interference with a right at all. At point $\mathrm{X}$ there is an interference but it is justified so there is no violation. ${ }^{193}$ At point $Y$ there is an 'interference' with a right, but justified only because it is held to fall within the MoA for the State concerned. On this analysis the MoA can be understood to be a means by which there is a violation but, because of the MoA, it is justified or excused. It is submitted that this is a misunderstanding. That a situation falls within the MoA simply means there is no violation of the ECHR. It is not a justified or excused violation. The crucial point is to ensure that the State does not fall below the bottom of the margin, to Point Z. This is illustrated in Fig 2.

Fig 2: Correct Understanding of the Margin of Appreciation

${ }^{193}$ In Eweida and Others $v$ UK, A. 48420/10, 59842/10, 51671/10 and 36516/10, the ECtHR took a broader approach to what constituted an interference and so had to be justified. 


\section{W - NO INTERFERENCE}

\section{$X$ - INTERFERENCE BUT JUSTIFIED WITH OR WITHOUT REFERENCE TO THE MARGIN OF APPRECIATION = NO VIOLATION}

\section{Z - VIOLATION}

The Human Rights Committee maintains that it does not afford states a MoA. Thus its approach can be illustrated as follows:

Fig 3: No MoA 


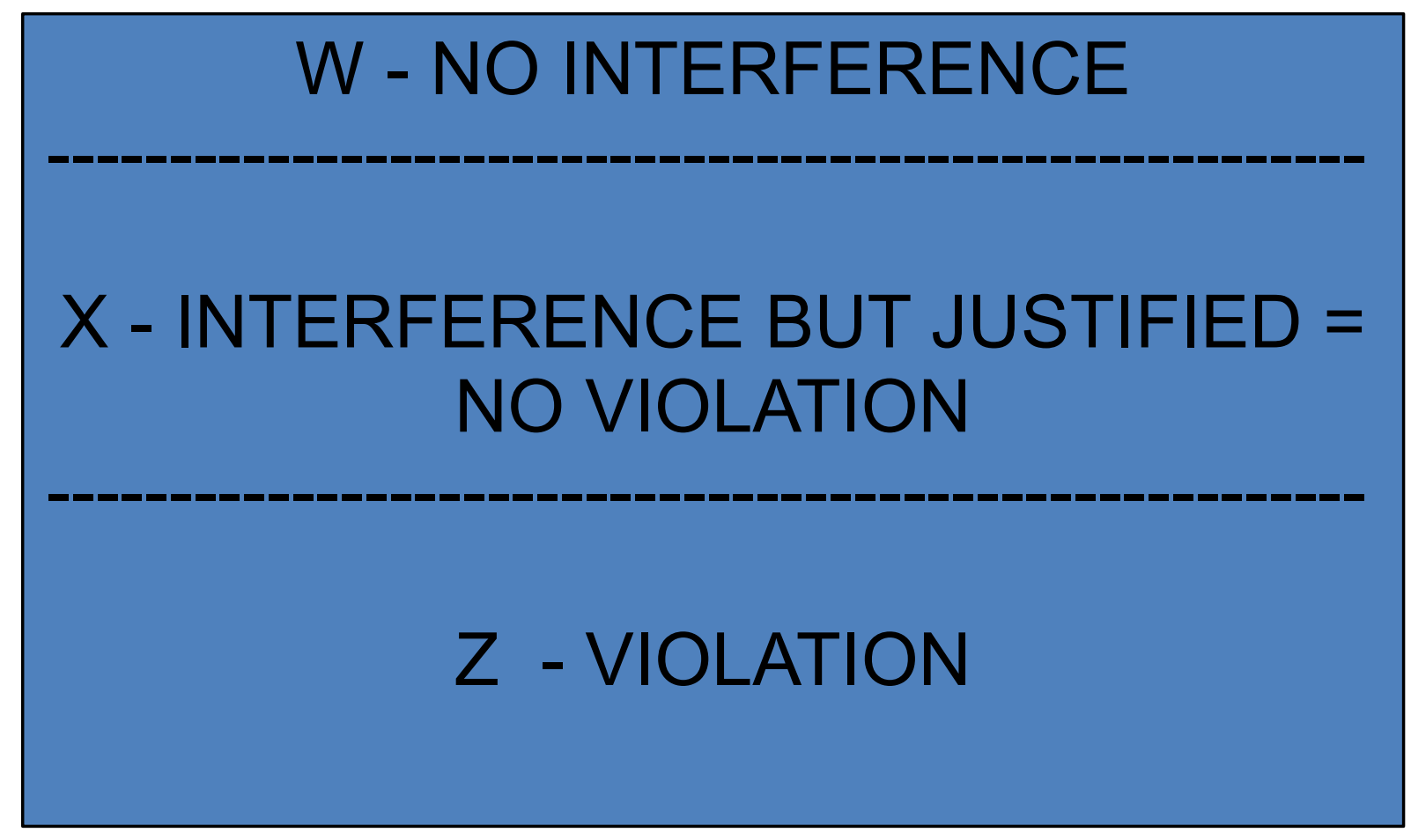

It can thus be seen that the critical issue is ultimately where point $\mathrm{Z}$ - the violation - is determined to be. ${ }^{194}$ On this analysis the significance of the ECtHR's use of the MoA is as an explanatory or justificatory device for where that point $\mathrm{Z}$ should be. Assume that there is a case concerning essentially the same right and permissible limitations under both the ECHR and the ICCPR. Both the ECtHR and the HRC determine that there is no violation. The ECtHR says it falls within the States MoA so there is no violation, while the HRC simply states there is no violation. The end result is that same. However, via the MoA the ECtHR can offer States more guidance and explanatory reasoning to States in terms of how to how close the State is or is not to violating the ICCPR. This in the series of cases concerning transsexuals the ECtHR warned the UK that it had to stay abreast of scientific research and understanding and respond accordingly with legislative review. ${ }^{195}$

If Fig 1 illustrated the correct operation and understanding of the MoA it would indeed be problematic. It would mean that the MoA was being used by the ECtHR to justify what the HRC would consider to be violations of the equivalent rights in the ICCPR. ${ }^{196}$

\footnotetext{
${ }^{194}$ For a critique of the violations approach, particularly its narrowness and levelling down effect, see Brems, supra n 00.

195 Supra n 00.

196 The cases considered in Part 00, section 00 [8 part 3??] below could be analysed on this basis
} 


\section{The non-Use of MoA by HRA is rhetorical}

A fourth possible explanation is that the HRC's opposition to the MoA is just rhetorical and the HRC has been 'speaking silently the language of the margin'. ${ }^{197}$ In a famous early case in 1982, Hertzberg v. Finland ${ }^{198}$ the HRC expressly used the MoA. The case concerned restrictions on expression justified by reference to public morals. The HRC stated that, 'public morals differ widely. There is no universally applicable moral standard.

Consequently, in this respect, a certain margin of discretion must be accorded to the responsible national authorities'. ${ }^{199}$ That remains the only express use of the MoA by the HRC. However, in practice the HRC does recognise that there can be differences between States and flexibility in the interpretation of ICCPR rights and remedies. The national context of the case can be critical to an assessment of whether rights have been violated. ${ }^{200}$ For example, the legal protection or measures a society or a State can afford to the family can vary from country to country and depend on different social economic, political and cultural conditions. ${ }^{201}$ Similarly, the concept of the 'family' can differ in some respects from State to State. ${ }^{202}$

As noted, the HRC has been clear that there is no MoA for States with respect to the determination of whether a member of a minority has been denied his right to enjoy his own culture under Article 27. ${ }^{203}$ However, it has accepted that measures that have a certain limited impact on the way of life of persons belonging to a minority will not necessarily amount to a

${ }^{197}$ J. Crawford, Preface to Arai-Takahashi, supra n 00, at ix.

${ }^{198}$ Cmn No. 61/1979, para 10.3. See also V.R.M.B. v. Canada, Cmn No. 236/1987, para 6.3

(it is not for HRC to test a sovereign state's evaluation of an alien's security rating).

${ }^{199}$ Ibid., para 10.3.

${ }^{200}$ See Mahuika v. New Zealand, Cmn No. 547/1993 (Fisheries Settlement and its enactment through legislation, including the Quota Management System, were compatible with article 27 with respect to Maori population); A. K. and A. R. v. Uzbekistan, Cmn No. 1233/2003, (restrictions on freedom of expression were concerned with a perceived threat to national security, via violent overthrow of the constitutional order, and to the rights of others. The HRC could not conclude that the restrictions imposed were incompatible with Article 19(3)); Borzov v. Estonia, Cmn No. 1136/2002, para 7.3 (HRC's role in in reviewing the existence and relevance of national security considerations depended on the circumstances of the case and the relevant provision of the Covenant. The refusal to grant B citizenship on national security grounds did not violate Article 26).

${ }^{201}$ Aumeeruddy-Cziffra v. Mauritius, Cmn No. 35/1978, para 9.2(b)(ii).

202 General Comment 19, para 2.

${ }^{203}$ Länsman et al. v. Finland, supra n 00. 
'denial' of the right under Article 27. ${ }^{204}$ States have thereby been afforded considerable room to authorise economic development that have had an impact on Article 27 rights. ${ }^{205}$ Where the ECtHR has had to consider similar issues, although framed within the context of Article 8 ECHR (private life), as in Noack v. Germany ${ }^{206}$ it has essentially analysed the same issues. It has looked at legitimate aim, necessity, proportionality, impact and stressed the importance of deliberative processes, consultation and continuing protection. Its conclusions reference the MoA but the substance of the approach is arguably the same. ${ }^{207}$

So it could be that HRC effectively affords States a MoA, but it just does not use the rhetorical language of the MoA. ${ }^{208}$ If so, it is offering States less guidance and explanatory reasoning to States than the ECtHR in terms of how to how close the State is or is not to violating the ICCPR, that is, proximity to point $\mathrm{Z}$.

\section{E. Lack of trust in decisions made by States Parties}

A fifth explanation might proceed along supposedly undiplomatic but realpolitik lines. European states have accepted substantial inroads into their sovereignty via the now compulsory jurisdiction of the ECtHR (and the European Union). But the ECtHR can afford States parties a MoA because it can trust their national authorities to take democratically based decisions. Decisions in many States in Europe are indeed reached on the basis of commendable democratic processes. Their functioning democratic basis is undoubtedly stronger than in other parts of the world. However, to only apply the MoA on the precondition of a functioning democracy would be problematic. It is Eurocentric and rather condescending. Classification into democratic and non-democratic States would be difficult

\footnotetext{
${ }^{204}$ Ibid. No violation was found.

${ }^{205}$ See Lansman v. Finland, Cmn No. 671/95 (no violation); Lansman v. Finland, Cmn No. 1023/2001 (no violation); Aarela and Nakkalajarvi v. Finland, Cmn No. 779/97 (no violation); Howard v. Canada, Cmn No. 879/1999 (no violation). A violation was found in Poma Poma v. Peru, Cmn No. 1457/2006 (P's way of life and culture had been substantively compromised and there had been no consultation).

${ }^{206}$ A. 46346/99), 25 May 2000, admissibility decision, Rep. 2000-VI.

${ }^{207}$ See also G. and E. v. Norway, A. 9278/81 and 9415/81, Commission, 3 October 1983, DR 35, p. 30; Buckley v. UK, A. 20348/92, (1996); Chapman v. the United Kingdom, A. 27238/95, (2001); Connors v. United Kingdom, A. 66746/01 (2004).

${ }^{208}$ See Schmidt, supra $\mathrm{n} 00$ at 656-8.
} 
in the absence of universally accepted indicators. ${ }^{209}$ A state of democracy is often reached via transition and process rather than an absolute state. Democratic standards vary considerable across Europe particularly after the expansion eastwards. ${ }^{210}$ The ECtHR has a massive caseload and continues to finds many democratic States to have violated fundamental rights in the ECHR, including non-derogable rights. Many findings of violation of the ECHR are based on a lack of proportionality in the democratically adopted measures. There are also many functioning democracies outside of Europe.

Moreover, non-European States are, arguably, even more fiercely defensive of their sovereignty and their domestic jurisdiction than European States. They may also be members of regional organisations but their monitoring and enforcements systems are generally weaker than under the ECHR. Basing a MoA on trusting the democratic credentials of States would create a real risk of double standards. States have the primary responsibility to protect international human rights. States should be able to have their human rights defences, for example based on necessity, proportionality, practicability, resources - indeed all of the kinds of issues looked at the by the HRC - and judged on the merits, without any preconceptions of lack of trust or lack of democratic credentials. There is also the question of what to do with the large number of European democracies that are also parties to both the ECHR and the ICCPR. Presumably there is no question of having a differentiated approach for them or for other States adjudged, a priori, to have high democratic standards. ${ }^{211}$ Of course, in assessing an individual case, considerable weight could be afforded to exacting and pertinent reviews, by both parliamentary and judicial bodies. But that is just a matter of evidential weight. The more States take account of human rights standards in coming to a decision the more likely it is that they will comply with those standards. In addition, three Articles of the $\operatorname{ICCPR}(14,21$ and 22) specifically refer to restrictions which can be imposed in a 'democratic society'.

\section{Similarities and Differences Between the European Court of Human Rights/ ECHR and the Human Rights Committee/ ICCPR}

\footnotetext{
${ }^{209}$ See Freedom in the World 2014, Freedom House's annual country-by-country report on global political rights and civil liberties, available at https://freedomhouse.org/report/freedom-world/freedom-world-2014\#.VIWhPE1 yaUk. ${ }^{210}$ See J.A. Sweeney, 'Margins of Appreciation: Cultural Relativity and the European Court of Human Rights in the Post-Cold War Era' (2005) 54 International Comparative Law Quarterly 459; L. Hammer and F. Emmert, The European Convention on the Human Rights and Fundamental Freedoms in Central and Eastern Europe (The Hague: Eleven, 2011).

${ }^{211}$ Cf Ni Aolain, 'The Emergence of Diversity: Differences in Human Rights Jurisprudence' (1995) 19 Fordham International Law Journal 114.
} 


\section{A Similarities and Differences}

To return to our opening question: why has the HRC, the implementing body under the ICCPR, made a point of not using the concept of a 'margin of appreciation'? The ICCPR is essentially the equivalent of the ECHR only at the global level. ${ }^{212}$ The ICCPR is in substance the same as the ECHR. The civil and political rights covered, and the language used, are broadly similar. The HRC follows many of the interpretative approaches of the ECtHR - the living instrument approach, ${ }^{213}$ purposive interpretation in accordance with object and purpose,${ }^{214}$ the autonomous meaning of ICCPR terms, ${ }^{215}$ reliance upon international standards, ${ }^{216}$ affording a wide scope to rights and a narrow scope to limitations narrowly, ${ }^{217}$ its complementarity with other international law rules, ${ }^{218}$ The central justifications for the MoA under the ECHR - subsidiarity, democratic societies and democratic legitimation, institutional competence and comity, and the purpose of establishing minimum rather than harmonised [international as distinct from regional] human rights standards apply with equal if not greater force to the ICCPR. If anything, one might have thought that, given the greater diversity of 167 States parties across the world, there was an even stronger case for the HRC applying the MoA. Both logically, empirically and intuitively, a mechanism at an international level needs to have more flexibility than one at any regional one. If the universal system imposed higher universal standards, because it does not allow states a MoA, it makes the regional systems appear problematic. ${ }^{219}$ This is because regional systems are not seen as a challenge to universal human rights as long as they have higher minimum standards than the universal ones.

That the ECtHR is a judicial institution, a Court, while the HRC is, at best, a quasijudicial committee of independent experts, does seem to provide any justification for a different approach to the issue of a MoA. It is more difficult to say that is the HRC rather than States that should act as the ultimate protector of human rights. ${ }^{220}$ Even the strongest critics of

\footnotetext{
${ }^{212}$ Schmidt, 'The Complementarity of the Covenant and the ECHR' in Harris and Joseph (eds) The ICCPR and UK Law (Oxford: OUP, 1995) 629.

${ }^{213}$ See Judge v. Canada, Cmn No. 829/1998, para 10.3.

${ }^{214}$ See .... [T and T case]

215 See ....

${ }^{216}$ See ... SMR's? CRC?

${ }^{217}$ See GC 34, supra n 00 on Freedom of Expression in Article 19 ICCPR.

${ }^{218}$ See The Nature of the General Legal Obligation Imposed on States Parties to the Covenant, GC 31, para 11.

${ }^{219}$ See the cases discussed in Part 00 infra.

${ }^{220}$ Cf Gross and F. Ni Aolain, supra n 00.
} 
the MoA afforded to States by the ECtHR in cases of emergencies accept that a certain MoA ought to be given to governments to deal with exigencies and acute crises. Their criticism was rather that it should be a narrow one, the bare minimum, rather than a wide one. ${ }^{221}$

\section{(b) Complementary Jurisprudence}

If essentially the same decision is reached then whether the ECtHR's use of the MoA is rhetorical or the HRC's non-use is rhetorical is academically interesting but ultimately insignificant in terms of substance. It is notable that there have been relatively few instances where the HRC and the ECtHR have clearly differed on their assessments with respect to the interpretation of their respective instruments. In many instances the second decision has referenced the first or clearly been taken with knowledge of the first. ${ }^{222} \mathrm{~A}$ good example is the cases concerning religious instruction in Norway. The HRC has held that such instruction will not satisfy the tests of neutrality and objectivity required by Article 18 ICCPR if it gives priority to one religion (e.g. Christianity) over another or if it involves the actual practice of a religion rather than the imparting of information. The instruction of 'Christian Knowledge and Religious and Ethical Education' (CKREE) in Norwegian public schools in 1997 was held to have failed on both these counts in Leirvåg et al $v$. Norway, ${ }^{223}$ decided in November 2004. The HRC then considered whether the system of exemptions in fact led to a situation where the teaching provided to those children and families opting for such exemption would be neutral and objective. Only partial exemption was possible and in some circumstances reasons for the request had to be given. The HRC closely scrutinized the framework and practical implementation of an exemption system and found a breach of Article 18(4) (respect for the liberty of parents and, when applicable, legal guardians to ensure the religious and moral education of their children in conformity with their own convictions). ${ }^{224}$ Despite modifications introduced after the decision of the HRC, in 2007 the Grand Chamber of the ECtHR found, by nine votes to eight, that there had been a violation of Article 2 of Protocol No. 1 to the ECHR (parents' right to respect for their convictions). The minority of eight did not find that the arrangements for a partial exemption entailed an excessive or unreasonable burden for parents who wished to make a request for an exemption, transgressed Norway's MoA. The minority regarded the scope of the case before the ECtHR as more limited than

\footnotetext{
${ }^{221}$ Ibid., at 648.

${ }^{222}$ See .... Al-Skeini - citing HRC's decisions; .... citing ECtHR's decisions.

${ }^{223}$ Cmn No. $1155 / 2003$, para 14.3 .

${ }^{224}$ Ibid., paras 14.4-14.5.
} 
that reviewed on the merits by the HRC and did not view its conclusions as contradicting those reached by the HRC.

\section{(c) Conflicting Jurisprudence}

It is particularly instructive to consider the small number of cases where the HRC has reached a different decision on the substance of essentially the same issue and consider whether it was the non-use of the MoA that made the difference.

\section{(1) Regulation of religious dress on residence and identity documents}

In 2008 in Mann Singh v. France ${ }^{225}$ the ECtHR Court accepted that identity photographs on driving licences which showed MS, a Sikh, bareheaded were needed by the authorities in charge of public safety and law and order, particularly in the context of checks carried out under the road traffic regulations, to enable them to identify the driver and verify that he or she was authorised to drive the vehicle concerned. It stressed that checks of that kind were necessary to ensure public safety within the meaning of Article 9(2) ECHR. It considered that the detailed arrangements for implementing such checks fell within France's MoA, especially since the requirement for persons to remove their turbans for that purpose or for the initial issuance of the licence was a sporadic one. It therefore held that the impugned interference had been justified in principle and was proportionate to the aim pursued. The application was declared manifestly ill-founded without even communicating it to the State any without any more detailed reasoning and analysis. 226

In two decisions in 2011 and 2013 the HRC took completely the opposite view. Ranjit Singh v. France ${ }^{227}$ in 2011 concerned a refusal to renew a residence permit in the absence of an identity photograph showing RS, a Sikh, bareheaded. RS claimed that because he did not have a residence permit, he no longer had access to the public health-care system or to social benefits. RS did not make an application to the ECtHR on the basis that its established jurisprudence was against him. He cited national court decisions and the decision pf the ECtHR in Mann Singh v. France, considered above, in support of this. There was no

${ }^{225}$ A. 24479/07 (13 November 2008).

${ }^{226}$ In a controversial ruling the HRC has decided that where the ECtHR declared a matter manifestly ill founded, it had not 'considered' the application and so it could be considered again by the HRC despite a reservation by the State precluding reconsideration. See Gerards, 'Inadmissibility Decisions of the European Court of Human Rights: A Critique of the Lack of Reasoning' (2014) 14 Human Rights Law Review 148.

${ }^{227}$ Cmn No. $1876 / 2000$. 
dispute that the measure was prescribed by law and had the legitimate aim of ensuring and verifying, for the purposes of public safety and public order, that the person appearing in the photograph on a residence permit is in fact the rightful holder of that document. The HRC asserted that it was for it to determine whether Article 18(3) ICCPR was satisfied. Its task was to decide whether that limitation was necessary and proportionate to the end sought. It unanimously decided that it was not as,

the State party has not explained why the wearing of a Sikh turban covering the top of the head and a portion of the forehead but leaving the rest of the face clearly visible would make it more difficult to identify the author than if he were to appear bareheaded, since he wears his turban at all times. Nor has the State party explained how, specifically, identity photographs in which people appear bareheaded help to avert the risk of fraud or falsification of residence permits. ${ }^{228}$

Consequently, the France had not demonstrated that the limitation placed on RS was necessary within the meaning of Article 18(3). It also observed that,

even if the obligation to remove the turban for the identity photograph might be described as a one-time requirement, it would potentially interfere with the author's freedom of religion on a continuing basis because he would always appear without his religious head covering in the identity photograph and could therefore be compelled to remove his turban during identity checks. The Committee therefore concludes that the regulation requiring persons to appear bareheaded in the identity photographs used on their residence permits is a limitation that infringes the author's freedom of religion and in this case constitutes a violation of article 18 of the Covenant. ${ }^{229}$

Essentially the same approach was followed Mann Singh v. France, ${ }^{230}$ decided by the HRC in 2013. MS, a Sikh, and the same individual who had earlier brought a case to the ECtHR, ${ }^{231}$ had obtained a series of French passports, for each of which he had been photographed wearing his turban. However, when he sought a renewal in 2005 he was informed that,

\footnotetext{
${ }^{228}$ Ibid., para 8.3.

${ }^{229}$ Ibid.

${ }^{230}$ Cmn No. $1928 / 2010$.

${ }^{231}$ Supra n 00.
} 
pursuant to a Decree of 2001, he was obliged to be photographed without the turban. Challenges before the French courts and, as noted, before the ECtHR failed. Although the factual issue before the HRC was different, France specifically pointed out that MS was effectively asking the HRC to disagree with the French courts and the ECtHR. It pointed to the similarity of wording between Article 9 ECHR and Article 18 ICCPR, the very strong similarity between the cases and the high level of protection of human rights afforded by both the ECtHR and the HRC. France claimed that the requirement was authorized by Article $18(3)$ as it responded to, 'the need to limit the risk of fraud or falsification of passports and facilitates the identification of the passport holder by the administrative authorities, while the constraints involved are only temporary. ${ }^{232}$

Nonetheless, the HRC asserted that it was for it to determine whether Article 18(3) was satisfied. Again, there was no dispute that the measure was prescribed by law and had the legitimate aim of ensuring and verifying, for the purposes of public safety and public order, that the person appearing in the photograph on a passport was in fact the rightful holder of that document. The HRC's task was to decide whether that limitation was necessary and proportionate to the legitimate aim. It unanimously decided that it was not. The HRC made the same observations on France's explanations and the continuing basis of the interferences as in the Ranjit Singh case. Again, therefore, the HRC concluded that the regulation requiring persons to appear bareheaded in their passport photographs was a disproportionate limitation that infringed the MS's freedom of religion and constituted a violation of Article 18. ${ }^{233}$

It is possible to distinguish the cases decided by the ECtHR and the HRC. Inability to travel outside of France because of the absence of a passport (the issue in Mann Singh before the HRC) would have a fundamental effect on freedom of movement. ${ }^{234}$ Inability to obtain a driving licence (the issue in Mann Singh before the ECtHR) was of a lesser order but nonetheless of immense practical significance to the daily lives of individuals. The HRC's decision in Ranjit Singh (concerning a residence permit which was important for lots of practical reasons including access to health care and social benefits) suggests that distinguishing between the cases in this way is not defensible. If not, then there is just a blatant difference between the jurisprudence of the HRC on one side and the French courts

\footnotetext{
${ }^{232}$ Cmn No. 1928/2010, para 9.2.

${ }^{233}$ Ibid., paras 9.4-9.5.

${ }^{234}$ See S.O. Chaib, 'Mann Singh wins turban case in Geneva after losing in Strasbourg' 19 Nov 2013, available at http://strasbourgobservers.com/2013/11/19/mann-singh-wins-ingeneva-after-losing-in-strasbourg/
} 
and the ECtHR on the other. The rights and limitations being applied are essentially the same. The narrowest explanation of the difference is that the HRC just reached a different position in terms of a factual assessment of how the restrictions would practically affect identification issues and the continuing nature of the interferences. It considered that the French explanations of the identification difficulties in both cases were unconvincing. Another explanation is that the HRC just took a stricter view on the proportionality of the measures. If so, it is disconcerting for States that what one international human rights institution unanimously considers proportionate, another unanimously considers disproportionate. A final explanation is that the ECtHR afforded the State a MoA that the HRC does not and the actual effect is to lower human rights standards as feared by critics of the MoA. Consistent with its established jurisprudence, neither of the HRC's views made any reference to any MoA.

What is unhelpful is that we can only speculate on these possible explanations. Given that France had specifically raised the issue of divergent interpretations, much more by way of explanation and reasoning should be expected from the HRC, in particular in relation to its assessment of proportionality. In particular it might have been thought important to discuss other States' practices. In Mann Singh before the HRC the author claimed, inter alia, that 'most European countries and others such as Australia, Canada, New Zealand and the United States of America, which have the same concerns as France regarding security and fraud, allow religious symbols to be worn on the head in identity photographs. France is the only country of the European Union that requires passport photographs to be bareheaded. ${ }^{, 235}$ Such a discussion could have suggested that the ECtHR should have found a violation even on the basis of its own approach to consensus as an aspect of the MoA. ${ }^{236}$

\section{(2). Regulation of religious dress in schools}

Even more striking is the divergent jurisprudence on the regulation of religious dress in schools. Ranjit Singh v. France ${ }^{237}$ and Jasvir Singh v. France ${ }^{238}$ concerned pupils in schools wearing a keski (a small light piece of material of a dark colour, substituting for a turban)

\footnotetext{
${ }^{235}$ Mann Singh v. France, para 7.3.

${ }^{236}$ See part 00 above.

${ }^{237}$ A. 27561/08.

${ }^{238}$ A. $25463 / 08$
} 
while Aktas v. France ${ }^{239}$ and three other cases ${ }^{240}$ concerned Muslim pupils wearing a bonnet (substituting a headscarf). The five cases challenged a French Law of 15 mars 2004, (loi no 2004-228) entitled 'en application du principe de laïcité, le port de signes ou de tenues manifestant une appartenance religieuse dans les écoles, collèges et lycées publics'. The law prohibited 'le port de signes ou tenues par lesquels les élèves manifestent ostensiblement une appartenance religieuse'. In 2009 the ECtHR declared the claims of all these applicants manifestly ill-founded in similar inadmissibility decisions. The decisions were based on the detailed reasoning used in 2008 judgments of Dogru v. France and Kervanci v. France ${ }^{241}$ concerning pupils who were prohibited to wear a headscarf during sport education classes. In these cases, the ECtHR referred to earlier judgments in which it held that it was for the national authorities, in the exercise of their MoA, to take great care to ensure that, in keeping with the principle of respect for pluralism and the freedom of others, the manifestation by pupils of their religious beliefs on school premises did not take on the nature of an ostentatious act that would constitute a source of pressure and exclusion. In the ECtHR's view, that concern did indeed appear to have been answered by the French secular model. ${ }^{242}$ Having regard to the MoA which must be left to the member States with regard to the establishment of the delicate relations between the Churches and the State, religious freedom recognised and restricted by the requirements of secularism appeared legitimate in the light of the values underpinning the ECHR. ${ }^{243}$ The conclusion reached by the national authorities that the wearing of a veil, such as the Islamic headscarf, was incompatible with sports classes for reasons of health or safety was not unreasonable. The penalty imposed was merely the consequence of the applicant's refusal to comply with the rules applicable on the school premises - of which she had been properly informed - and not of her religious convictions, as she alleged. ${ }^{244}$ In the five cases in 2009 the ECtHR saw no reason to deviate from this case law even though the scope of the 2004 prohibition legislation was wider than a prohibition to wear headgear in sport education classes. The fact that the national authorities considered that more 'discrete' headgear such as a keski instead of a turban and a bandana or bonnet instead of a headscarf that the applicants wore still came within the prohibition in the national

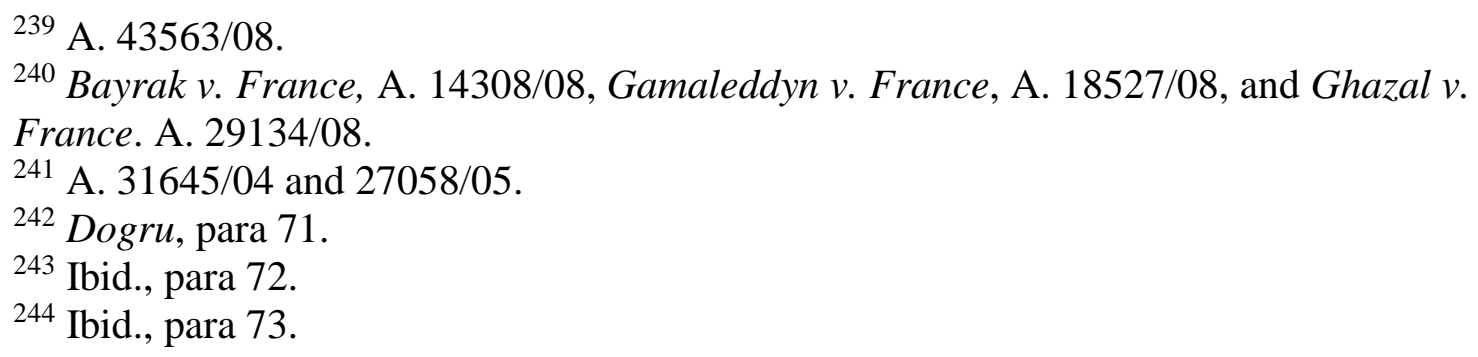


legislation came within the State's MoA. The reasoning of the national authorities was not unreasonable. ${ }^{245}$

The HRC has taken completely the opposite view to the same issue. ${ }^{246}$ In 2013 in Bikramjit Singh v. France ${ }^{247}$ BS was denied access to his classes at school because of the wearing of a keski, in place of a turban. The decision was based on the 2004 French legislation considered by the ECtHR in Dogru and the other French cases noted above. Initially BS he had to sit in the school's canteen to study on his own. After a short period of dialogue between the school authorities and BS's family, the school expelled BS from school since he refused to comply with the school's demand to remove his keski in the school premises. Interestingly both BS and the State made reference to the idea of a State having a MoA. ${ }^{248}$ France cited the case law of the ECtHR, specifically the Dogru and Kervanci cases, which allowed States parties to the ECHR some room for manoeuvre. It submitted that this reflected the Court's intention to take account of choices, particularly constitutional and legislative choices, made by States attached to the principle of secularism, while monitoring observance of the rights and freedoms protected by the ECHR. ${ }^{249}$

Again the HRC asserted that it was responsible for deciding whether any limitation was necessary and proportionate to the end sought, as defined by the State. The HRC recognized that the principle of secularism (laïcité) was itself a means by which a State may seek to protect the religious freedom of all its population, and that the adoption of Act No. 2004-228 responded to actual incidents of interference with the religious freedom of pupils and sometimes even threats to their physical safety. Therefore, it considered that Act No. 2004-228 served purposes related to protecting the rights and freedoms of others, public order and safety. Moreover, the HRC noted that the regulation was adopted in response to certain contemporary incidents. The HRC also noted S's statement, not challenged by the State, that for Sikhs males, wearing a keski or turban was not simply a religious symbol, but an essential

${ }^{245}$ See R. Negro, 'The Margin of Appreciation Doctrine and the Case-Law of the European Court of Human Rights on the Islamic Veil' (2010) 11 Human Rights Review 531

${ }^{246}$ See S.O. Chaib, 'Freedom of Religion in Public Schools: Strasbourg Court v. UN Human Rights Committee' 14 Feb 2013, available at http://strasbourgobservers.com/2013/02/14/freedom-of-religion-in-public-schools-strasbourgcourt-v-un-human-rights-committee/

${ }^{247}$ Cmn No. $1852 / 2008$.

${ }^{248}$ Ibid., para 3.5 .

${ }^{249}$ Ibid., para 5.5. 
component of their identity and a mandatory religious precept. It also noted the State's explanation that the prohibition of wearing religious symbols affected only symbols and clothing which conspicuously display religious affiliation did not extend to discreet religious symbols and the Council of State took decisions in this regard on a case-by-case basis. However, the HRC was of the view that the State had 'not furnished compelling evidence that, by wearing his keski, $S$ would have posed a threat to the rights and freedoms of other pupils or to order at the school'. ${ }^{250}$ It was also of the view that the penalty of the pupil's permanent expulsion from the public school was disproportionate and led to serious effects on the education to which S, like any person of his age, was entitled in the State. ${ }^{251}$ It was convinced that expulsion was necessary and that the dialogue between the school authorities and the author truly took into consideration his particular interests and circumstances. Moreover, the State imposed this harmful sanction on S, not because his personal conduct created any concrete risk, but solely because of his inclusion in a broad category of persons defined by their religious conduct. ${ }^{252}$ In this regard, the HRC noted the State's assertion that the broad extension of the category of persons forbidden to comply with their religious duties simplified the administration of the restrictive policy. However, in the HRC's view, the State had not shown how the sacrifice of those persons' rights was either necessary or proportionate to the benefits achieved. For all these reasons, the HRC concluded that the expulsion of the author from his lycée was not necessary under Article 18(3), infringed his right to manifest his religion and constituted a violation of Article $18 .^{253}$

Distinguishing the approaches of the HRC and the ECtHR is even more difficult in these cases. They appear manifestly inconsistent on the same issue. Again there is no reference to the MoA by the HRC. One commentator has been supportive of the HRC's approach:

While the ECtHR views the cases merely in light of the interests of the State, the UN Committee balances the arguments of all parties in a more convincing way, taking the fundamental rights of the applicants seriously all the while acknowledging the State's interests. Hence, with this case the UN Committee gives again a clear signal that a

\footnotetext{
${ }^{250}$ Ibid., pr. 8.7 (emphases added).

${ }^{251}$ There is no right to education in the ICCPR.

${ }^{252}$ Bikramjit Singh, pr. 8.7.

${ }^{253}$ Ibid. Having ascertained that a violation of Article 18 occurred, the HRC did not examine the claim based on a separate violation of the principle of non-discrimination guaranteed by Article 26.
} 
general principle such as secularism, however important, cannot blindly trump individuals' rights, such as the right to freedom of religion, without looking at the particularities of the case. ${ }^{254}$

Such an approach places great weight on the individuals' rights against those of the wider community represented by the State. When restrictions are imposed on the basis of general principles such as secularism it is impossible for the State to provide compelling evidence that, by wearing his keski, S would have posed a threat to the rights and freedoms of other pupils or to order at the school or that his personal conduct created any concrete risk. ${ }^{255}$ That is too individualistic an approach and would fail in the vast majority of cases. The threat comes not from the single individual but from the combined effect of all the religious individuals concerned. As the ECtHR has observed, concessions on the part of individuals or groups of individuals can be justified in order to maintain and promote the ideals and values of a democratic society. ${ }^{256}$ Arguing that a general principle such as secularism 'blindly trumps' an individuals' rights does not give proper weight and appreciation to a general principle that, as both the ECtHR and HRC accept, seeks to protect the religious freedom of all its population. It is submitted that the lack of reasoning and explanation of the HRC do not do justice to this issue. Again it also puts the State concerned, France, and other States relying on the established jurisprudence of the ECtHR in a very difficult position. If the HRC is clearly aware that it is disagreeing with the established jurisprudence of the ECtHR, or any other regional human rights body, it surely has some responsibility to provide a detailed justification for that. It is notable that France has taken no action to action taken to implement the HRC's recommendations in Ranjit Singh v. France, Mann Singh v. France and Bikramjit Singh v. France.

It has been reported that the board of Flemish public schools in Belgium will introduce a blanket ban on religious symbols in all their schools starting from the 2015 school year. Belgium is also a party to the ICCPR and has accepted the HRC's jurisdiction to hear individual complaints under OP1. ${ }^{257}$ The decision in Bikramjit Singh v. France might give it

\footnotetext{
${ }^{254}$ See Chaib, supra $\mathrm{n}$ 00. There is also a broader critique that the ECtHR has not been strong enough in its defence of the rights of religious believers. As noted, Eweida and Others v. UK, supra $\mathrm{n} 00$, moves the ECtHR's jurisprudence more firmly into the necessity for balancing and away from notions of non-interference.

${ }^{255}$ The same was true of the individual in the Sahin v. Turkey case, supra $\mathrm{n} 00$.

${ }^{256}$ Şahin v. Turkey, supra n. 00

${ }^{257}$ Ibid.
} 
pause for thought. The terms of OP1 mean that individuals can go to the HRC after the ECtHR. ${ }^{258}$ One of the consequences of such a fundamental divergence in interpretation is that individuals may go to the HRC after the ECtHR, or simply go to the HRC rather than to the ECtHR, even though the result is a non-legally binding view rather than a legally binding judgment. $^{259}$

\section{The non-use of the Margin of Appreciation within the Inter-American Convention on Human Rights System}

The Inter American Court of Human Rights (IACtHR) relies extensively on jurisprudence of ECtHR. ${ }^{260}$ There have been decisions making express reference to the MoA. ${ }^{261}$ In its opinion on Naturalization Provisions Costa Rica, Opinion - Proposed Amendments to the Naturalization Provisions of the Constitution of Costa Rica, the IACtHR stated that '[o]ne is here dealing with values which take on concrete dimensions in the face of those real situations in which they have to be applied and which permit in each case a certain margin of appreciation'. ${ }^{262}$ However, it has been argued by Candia that the Inter-American system differs from the ECHR system in not systematically afforded States a MoA in cases involving

${ }^{258}$ Unless the State has made a reservation to OP1 to preclude this. See also Gerards, supra $n$ 00 .

${ }^{259}$ See E. Brems et al, 'Le port de signes religieux dans l'espace public: verité à Strasbourg, erreur à Genève?’ Journal des Tribunaux, 2012, 602-603.

${ }^{260}$ Refs? Harris Livingstone??

${ }^{261}$ In 1993, in José Ríos-Montt v. Guatemala, the Inter-American Commission considered that the issue of the constitutional ineligibility of former dictators from being candidates for the presidency should be analyzed in light of the circumstances of the individual case and prevailing concepts in the historic period. The Commission reaffirmed 'the restrictive character that this margin of appreciation should utilize, which should always be conceived with a view to strengthening the system and its objectives', para 29. The grounds for ineligibility had emerged from an act of a Constitutional Convention elected by democratic vote in which the Guatemalan people decided through their representatives at that convention that it was necessary to maintain such grounds, which are already founded in Guatemala's constitutional history and moreover to make them permanent. Within those conditions any constitutional system of law possessed the right to make its operation more effective, and to defend the integrity of its citizens' rights. The application was declared inadmissible. Case 10.804, Inter-Am. Commission H.R., Report No. 30/93, OEA/Ser.L/V.85, doc. 9, rev. (1993).

${ }^{262}$ Series A, No. 4 (1984) para 58. 
the lack of regional consensus. ${ }^{263}$ His explanation for this was grounded both in history, politics and the Court's respective self-perceptions.

\section{A. History}

Candia's historical explanation for rejecting deferential approaches during the early years of the Inter-American system was the existence of military dictatorships on the continent. Their legislative decisions, in most of the cases, lacked any democratic legitimacy. Indeed, in many cases, the governments concerned directly conducted the infringement of absolute human rights. Many of the cases concerned situations of gross and systematic violations where the issues were mainly factual and so the MoA simply would have had no application in any event. ${ }^{264}$

\section{B. Conceptual Approach}

Even after the return of democracy to the continent, the inter-American human rights institutions refused to change their aggressive standard of review. This was so even in cases concerning conflicts between rights in the ACHR and about matters subject to profound disagreement in the Americas. In 1999 in Andrés Aylwin et al. v. Chile ${ }^{265}$ the Commission found that the Chilean constitution infringed on political rights by discriminating in favour of some privileged electors. In the Baby-boy case ${ }^{266}$ in 1981 the Commission held that Article 4 $\mathrm{ACHR}$, protecting the right to life 'in general, from the moment of conception' permitted states to resolve the issue within their legislations, allowing or restricting abortion laws. This effectively afforded them a MoA. ${ }^{267}$ Presumably acting within its understanding of the MoA afforded to the State, the Supreme Court of Costa Rica had decided to afford protection to the unborn from conception, prohibiting in absolute terms all mechanisms of in vitro fertilization

${ }^{263}$ Candia, 'Comparing Diverse Approaches to the Margin of Appreciation: The Case of the European and the Inter-American Court of Human Rights' (9 March 2014), available at http://papers.ssrn.com/sol3/papers.cfm?abstract_id=2406705. Cf Legg???

${ }^{264}$ Most famously perhaps Velásquez-Rodríguez v. Honduras, Merits and Judgment, IntAmCtHR (ser. C) No. 4 (29 July 1988).

${ }^{265}$ Case 11.863, Inter-Am. Commission H.R., Report No. 95/98, OEA/Ser.L/V/II.102, doc. 6 rev. (1999), para 108. This decision can effectively be read to reverse the decision of the American Commission in 1993 in José Ríos-Montt v. Guatemala, supra n 00.

${ }^{266}$ See Christian B. White \& Gary K. Potter v. United States of America, Case 2.141, InterAm. Commission H.R., Report No. 23/81, OEA/Ser.L/V/II.85, doc. 9 rev. 1 (1981).

${ }^{267}$ See ibid, concurring opinion of Aguilar, at para 5. 
(IVF) that would threaten the right to life of embryos by allowing their cryopreservation or elimination. However, in 2012 in Artavia-Murillo et al. v. Costa Rica ${ }^{268}$ the IACtHR effectively decided that the State did not have a MoA to decide to afford protection to the unborn from conception by prohibiting in absolute terms all mechanisms of in vitro fertilization (IVF) that would threaten the right to life of embryos by allowing their cryopreservation or elimination. Costa Rica submitted that the IACtHR should respect its legislative decision as States enjoyed a MoA on the matter as there was no regional consensus in the Americas. However, the IACtHR read into the ACHR implicit rights to 'reproductive autonomy' and 'access to reproductive health,' which could not be denied or disproportionately restricted by the contracting states. It also decided that the ACHR provided legal protection to the unborn not from the moment of conception, but from the implantation of the embryo in the mother's uterus, which transpired later. ${ }^{269}$ Therefore, the imposition of any absolute prohibition of IVF whose purpose was to protect the life of the unborn between conception and implantation was misplaced and disproportionate. With respect to the State's argument about the lack of regional consensus concerning IVF regulations:

The Constitutional Chamber [of the Costa Rican Supreme Court of Justice] based itself on an absolute protection of the embryo that, by failing to weigh up or take into account the other competing rights, involved an arbitrary and excessive interference in private and family life that makes this interference disproportionate. Moreover, the interference had discriminatory effects. In addition, taking into account these conclusions about the assessment and the considerations concerning Article 4(1) of the Convention ..., the Court does not consider it pertinent to rule on the State's argument that it has a margin of appreciation to establish prohibitions such as the one established by the Constitutional Chamber. ${ }^{270}$

\footnotetext{
${ }^{268}$ Merits, Reparations and Costs, Preliminary Objections, Merits, Reparations, and Costs, IntAmCtHR (ser. C) No. 257, (28 Nov 2012).

${ }^{269}$ Cf Vo v. France [GC], supra n 00, where the ECtHR would not decide on the status of a foetus....

${ }^{270}$ Artavia-Murillo et al. v. Costa Rica, at para 316.
} 
In substance the IACtHR disregarded any appeal to the MoA. It imposed legislative rules on the States in areas where there was no consensus, or even a majority. Indeed, pervasive disagreement still existed. ${ }^{271}$

The IACtHR's judgement in Atala-Riffo et al. v. Chile ${ }^{272}$ (2012) was also striking for its disregard of issues concerning consensus. The complaint was that Chilean courts had discriminated against a lesbian in giving custody of her three daughters to their father. The final decision, issued by the Chilean Supreme Court, affirmed that the cohabitation of Ms. Atala-Riffo and her lesbian partner created a situation of risk and vulnerability for the AtalaRiffo's daughters to the extent that (a) it negatively impacted the regular growth of the girls; and (b) it exposed them to be discriminated by their peers. Chile argued that the decision of national courts had been justified on the grounds of the 'best interest of the child' principle. The national courts had decided that the father and his new family offered better conditions for the development of the minors. The sexual orientation of Ms. Atala-Riffo was simply one of the elements considered by the judgment. Therefore, the decision had not exclusively relied on that element. Moreover, there was no regional consensus concerning child custody laws in the Americas when the Chilean Supreme Court finally decided the case in 2004.

The IACtHR held that that (a) sexual orientation was a category protected by the nondiscrimination clause of the ACHR due to an evolutive interpretation of the rights contained by it; (b) the seeking of the best interest of the child had to eliminate all 'speculations, assumptions, stereotypes, or generalized considerations regarding the parents' personal characteristics or cultural preferences regarding the family's traditional concepts; therefore, the child's best interest could not be used to justify discrimination against the parents based on their sexual orientation and, (c) the arguments given by national courts to deprive Ms. Atala-Riffo from the custody of her daughters were not adequate. The Chilean Supreme Court had failed by not applying a strict scrutiny test to analyze the case. ${ }^{273}$ As to the lack of American consensus about the legitimacy of establishing differential treatments based on sexual orientation, the IACtHR stated that,

The alleged lack of consensus in some countries regarding full respect for the rights of sexual minorities cannot be considered a valid argument to deny or restrict their

\footnotetext{
${ }^{271}$ See Artavia-Murillo, ibid, Vío-Grossi, J., dissenting.

${ }^{272}$ Merits, Reparations and Costs, Preliminary Objections, Merits, Reparations, and Costs, IntAmCtHR (ser. C) No. 239, (24 Feb 2012).

${ }^{273}$ Ibid., paras 91-131.
} 
human rights or to perpetuate and reproduce the historical and structural discrimination that these minorities have suffered. The fact that this is a controversial issue in some sectors and countries, and that it is not necessarily a matter of consensus, cannot lead this Court to abstain from issuing a decision, since in doing so it must refer solely and exclusively to the stipulations of the international obligations arising from a sovereign decision by the States to adhere to the American Convention. ${ }^{274}$

This statement is striking. The parallel could be drawn to some extent with the Christine Goodwin Case decided by the ECtHR. ${ }^{275}$ However, that was more narrowly focussed on transsexuals and was the end result of a 16 year set of decisions which gradually reduced states margin of appreciation. The approach of the IACtHR is much more sweeping, dramatic and quasi-legislative. The absence of a consensus on the sensitive issue of differential treatments based on sexual orientation, instead of presumptively giving rise to at least a narrow MoA, was just ignored. An alternative reading is that the statement could be explained away as being confined to an issue concerning the historical and structural discrimination of minorities, on which a court may feel it has a strong claim to institutional competence. Stating that the IACtHR 'must refer solely and exclusively to the stipulations of the international obligations arising from a sovereign decision by the States to adhere to the American Convention' appears disingenuous given the evolutive interpretation the court adopted. It is also question-begging because the real issue is how the 'stipulations of the international obligations' are to be interpreted.

In another remarkable decision in 2011 in Juan Gelman v. Uruguay ${ }^{276}$ the IACtHR decided that amnesty laws that sought to stop the legal prosecution of members of the military after dictatorial regimes always constituted an unjustifiable infraction of the right to pursue truth and justice, which was implicitly recognized in Article 25 ACHR. The IACtHR adopted this standard in spite of the fact that the law concerned did not constitute a selfamnesty and it was supported by the majority of the population. The decision appears unrealistic and absolutist. It presents a substantial impediment to efforts to achieve

\footnotetext{
${ }^{274}$ Ibid., para 92 (emphasis added).

${ }^{275}$ Supra $\mathrm{n} 00$.

${ }^{276}$ Merits and Reparations, Inter-Am. Ct. H.R. (ser. C) No. 221, (24 Feb 2011).
} 
transitional justice. ${ }^{277}$ It is interesting to compare this with the decision of the HRC in O'Neill and Quinn v. Ireland ${ }^{278}$ concerning alleged discrimination by the executive with respect to the application of an early release scheme for prisoners. The HRC considered that it was not in a position to substitute the State party's assessment of facts with its own views, particularly with respect to a decision that was made nearly ten years ago, in a political context, and leading up to a peace agreement. It found that the material in front of it does not disclose arbitrariness and concluded that the authors' rights under Article 26 ICCPR to equality before the law and to the equal protection of the law had not been violated. In Marguš v. Croatia ${ }^{279}$ the applicant was granted amnesty for acts which amounted to grave breaches of fundamental human rights such as the intentional killing of civilians and inflicting grave bodily injury on a child, and the national court's reasoning referred to the applicant's merits as a military officer. The ECtHR stated that there was a growing tendency in international law was to see such amnesties as unacceptable because they were incompatible with the unanimously recognised obligation of States to prosecute and punish grave breaches of fundamental human rights. The ECtHR held that, '[e]ven if it were to be accepted that amnesties are possible where there are some particular circumstances, such as a reconciliation process and/or a form of compensation to the victims, the amnesty granted to the applicant in the instant case would still not be acceptable since there is nothing to indicate that there were any such circumstances. ${ }^{280}$ The position of the ECtHR is clearly less absolutist.

The IACtHR has also not applied a MoA to cases like Olmedo-Bustos et al. v. Chile ${ }^{281}$ in (2001) which concerned a conflict between ACHR rights - freedom of expression and the religious feelings of the population. The Chilean Supreme Court had upheld an order prohibiting the distribution of the film 'The Last Temptation of Christ'. The ECtHR would have applied a MoA analysis, and given significant weight to religious sensibilities, the absence of consensus regarding the form in which attacks on religious beliefs had to be treated among states and, privileged position enjoyed by domestic authorities at the time of resolving the tension between freedom of expression and the defence of religious

${ }^{277}$ See Malarino, 'Judicial Activism, Punitivism and Supranationalisation: Illiberal and Antidemocratic Tendencies of the Inter-American Court of Human Rights' (2012) 12 International Criminal Law Review 665.

${ }^{278}$ Cmn No. 1314/2004, para 8.4.

${ }^{279}$ A. $4455 / 10$ [GC].

${ }^{280}$ Ibid., para 139.

${ }^{281}$ Merits, Reparations and Costs, IntAmCtHR (ser. C) No. 73 (5 Feb 2001). 
sensibilities. ${ }^{282}$ By contrast the IACtHR directly scrutinized the substance of the Chilean Supreme Court's decision and condemned the state for violating freedom of expression because the prohibition of the exhibition of the film constituted prior censorship in violation of Article 13 ACHR. The IACtHR demanded a change in the constitutional provision that established a system of prior censorship by an administrative board. Chile followed the judgment and it modified its Constitution as the IACHR required in 2001.

\section{Institutional self-Perception}

Candia submitted that the concept of the MoA that international courts develop importantly relies on the conception that they have of themselves. ${ }^{283}$ In his view the ECtHR has always looked at itself as a supranational (probably meaning 'international' in this context) tribunal with subsidiary jurisdiction. On the contrary, the IACtHR, by adopting an aggressive standard of review based on proportionality, ignores the need of judicial deference. He cites the cases discussed in the pre-ceding section. Candia's thesis is that this self-perception pushes for an institutional transformation that makes the IACtHR a continental constitutional court with powers to standardize the understanding of the ACHR on the American continent. He bases this claim on three reasons: (a) the declarations made by some IACHR members; (b) the judicial creation of the 'conventionality control'. The IACtHR has decided to impose on all states the obligation of following its decisions, even to States that have not been a party in the case in which the judgment was made. ${ }^{284}$ In order to achieve that objective, the IACHR has sought to empower national courts to disapply domestic legislation when it goes against the text of the ACHR as constructed by the IACtHR. In practice, the 'conventionality control' limits the possibility of national institutions to interpret and construct the ACHR according to their own understanding; and (c) the extended use of the proportionality review by the IACHR, as evidenced by some of the cases considered in the preceding section. In this context, the use of the MoA within the Inter-American system becomes completely meaningless.

\footnotetext{
${ }^{282}$ See, for example, Otto-Preminger v. Austria; Wingrove v. UK; Murphy v. Ireland, A. 44179/98; I.A. v. Turkey, A. 42571/98).

${ }^{283}$ Candia, supra n 00, 21.

${ }^{284}$ Almonacid-Arellano et al. v. Chile, Preliminary Objections, Merits, Reparations, and Costs, IntAmCtHR (ser. C) No. 154 (26 Sep 2006).
} 
Candia accepts that the IACtHR is moving the ACHR system to a model of judicial supremacy that is not expressly contemplated in the ACHR. That model does not give weight to any democratic deficit of international courts or the lack of regional consensus regarding many issues in which moral disagreement is pervasive. In Candia's view this perception as a continental constitutional court is consistent with the desire of many academic and scholars who seek to transform this tribunal into the new constitutional court of the Americas with special powers to standardize domestic human rights legislation.

In relation to all three reasons given by Candia the ECtHR can be distinguished. Few judges on the ECtHR have described as being a 'Constitutional court' and when they have it has been in the much softer constitutional sense of tendencies, characteristics or elements. ${ }^{285}$ The ECtHR has encouraged national courts to follow its jurisprudence but has never sought to empower national courts to disapply domestic legislation. ${ }^{286}$ Finally, the ECtHR also makes extensive use of the proportionality review but usually accompanies this by making frequent reference to the MoA. The HRC would seem to be even further away from Candia's first two reasons. It is not even a court, never mind a world human rights court. It has never sought to empower national courts to disapply domestic legislation. The one ground of similarity between the IACtHR and the HRC is that they both apply a strict proportionality review but no doctrine of a MoA.

\section{Concluding Comments}

It is probably fair to say that there is no consensus amongst the ECtHR's judges on the MoA. However, the majority of them appear to take the view that if national authorities have fully considered a case by reference to the ECtHR's jurisprudence and come to clear reasoned decisions, then serious reasons would be needed to overturn such decisions. ${ }^{287}$ A minority of judges, while accepting the concept of the MoA as such, appear to take a less deferential

\footnotetext{
${ }^{285}$ See L. Wildhaber, 'A Constitutional Future for the European Court of Human Rights?' (2002) 11 Human Rights Law Journal 161. See also Follesdal et al, supra n. 00; Christoffersen and Madsen, supra n. 00; I. Cameron, 'Protocol 11 to the ECHR: The ECtHR as a Constitutional Court?' (1995) 11Yearbook of European Law 219; L. Wildhaber and S Greer, 'Revisiting the Debate about "Constitutionalizing” the ECtHR' (2012) 12 Human Rights Law Review 655.

${ }^{286} \mathrm{Cf}$ Of course the European Court of Justice has done exactly that within the context of the EU.

${ }^{287}$ See supra n 00; Friend and Countryside Alliance and Others v. UK, A.16072/06 and 27809/08, para 58 .
} 
approach. It is possible that this is partly out of a fear that they would be abdicating their judicial responsibilities. They see the ECtHR's role as being to set European human rights standards, not to defer to State's assessment of them. Under the ECHR system, it is that the ECtHR has 'ultimately interpretative responsibility'. ${ }^{288}$ These judges tend to consider each case afresh and take a stricter approach to assessing the actions of national authorities, particularly in terms of applying the principle of proportionality. The result is a greater tendency towards micro-management. There is also a fear that reliance on the MoA because of the absence of consensus could unintentionally lower national standards. ${ }^{289}$ This is particularly so with respect to the new States that joined after the end of the Cold War. However, in principle this should not happen as the ECHR itself safeguards existing levels of domestic human rights. ${ }^{290}$

The MoA gives States room for manoeuvre while retaining strong elements of European supervision. It is submitted that the complexity of factors taken account of in ECtHR's methodology of applying the MoA leads to reason-based, justificatory arguments. ${ }^{291}$ Most decisions of the ECtHR concern the internal, domestic application of human rights norms to individuals with the territory of the State concerned. There is a strong argument that the decisions adopted by the different levels of democratic processes within that territory should bear significant, but not necessarily decisive, weight. ${ }^{292}$ One may disagree with the reasons and the arguments, their factual or evidential basis or epistemic value, but these are different issues. There is thus a process of reasoning, contestation and evaluation which is engaged in by democratic Parliaments and courts and, to some extent, the people. ${ }^{293}$ Giving a significant

288 Yourow, supra n 00, 181.

${ }^{289}$ See P. Paczolay, 'Consensus and Discretion: Evolution or Erosion of Human Rights Protection?' in Dialogue Between Judges, supra n 00 (2008) with respect to the decision in Rekvenyi v. Hungary [GC], A.2390/94.

${ }^{290}$ See Article 53 ECHR. See also Kennedy v. Charity Commission, UK Supreme Court, [2014] UKSC 20, [2014] 2 WLR 808 (ECHR claim failed but claim sent back to judge to consider a stronger case based on common law).

${ }^{291}$ See e.g. S.H. v Austria, supra n. 113 (in striking the balance the Austrian Parliament stayed within the limits of MoA); Y. Arai-Takashi, The Margin of Appreciation Doctrine and the Principle of Proportionality (2002). See also M. Cohen-Eliya and I. Porat, (2011) 59 'Proportionality and the Culture of Justification' American Journal of Comparative Law 466. 292 The argument is obviously weaker when the case concerns that extra-territorial application of the ECHR because there no democratic accountability to the affected persons. See $\mathrm{Al}$ Skeini v UK [GC], A. 55721/07, (7 July 2011); Jaloud v. Netherlands, A. 47708/08 (20 November 2014).

${ }^{293}$ See B. Petkova, 'The Notion of Consensus as a Route to Democratic Adjudication?' (2011-12) 14 Cambridge Yearbook of European Legal Studies 663. 
but not necessarily determinative weight to the existence or non-existence of a consensus is a sensible and credible tool to ensure that the evolution of the ECtHR's jurisprudence keeps pace with but does not move so far ahead societal changes within Europe that it creates significant risk of non-implementation. The MoA can thus be understood as a device which mediates between the idea of universal human rights and leaving space for reasonable disagreement, legitimate differences, and national or local cultural diversity. ${ }^{294}$

It is submitted that when properly understood the MoA is a complex, sophisticated and defensible intellectual instrument ${ }^{295}$ - like a multi-dimensional chess game in which a lot of pieces are in play along a number of axes. An acceptable and human rights compliant overall balance can be achieved in a number of ways. Thus conceived the MoA plays a crucial role in building a complex multi-level community amongst the 47 Council of Europe States. In this respect, ECHR rights form an integral part of the wider democratic order and wider community, rather than some external limitation. It is an open question whether the express inclusion of references to subsidiarity and the MoA in the ECHR, via Protocol 15, will prove to be a significant watershed in the efforts of the contracting parties to the ECHR to be afforded a wider MoA, with consequential effects upon the jurisprudence under the ECHR? 'Subsidiarity' may perhaps be expected to make a more regular appearance in the jurisprudence of the $\mathrm{ECtHR}^{296}$ but it is likely that in most cases it will be used to support what would in any event have been the jurisprudence of the ECtHR, particularly when it is applying the MoA. ${ }^{297}$

We have considered various explanations for the lack of use of MoA by HRC. ${ }^{298}$ Views will differ on their validity and credibility. Some of the explanations appear more political than legal. However, in terms of harmonisation of international human rights law, it remains problematic that the central conceptual doctrine in the ECHR institutional and jurisprudential architecture is ignored by the HRC. In doing so it is submitted that they deprive themselves

\footnotetext{
${ }^{294}$ See D.L. Donoho, 'Autonomy, Self-Governance, and the Margin of Appreciation: Developing a Jurisprudence of Diversity Within Universal Human Rights' (2001) 15 Emory International Law Review 391.

${ }^{295}$ See also Legg, supra n 00, who strongly supports the use of the MoA.

${ }^{296}$ See e.g. Herrmann v Germany, A. 9300/07 (June 2012) in which the minority judges suggested that the case, which concerned the regulation of hunting on the land of private owners, was an 'excellent example of a case in which the principle of subsidiarity should be taken very seriously', Joint Dissenting Opinion of Judges Thór Björgvinsson, Vučinić and Nußberger (the national judge concerned), 50 at 52.

${ }^{297}$ See Spielmann, supra n 00; Spano, supra n 00.

${ }^{298}$ See Parts 00-00 infra.
} 
of a credible and defensible intellectual instrument for making human rights determinations. The MoA could assist the HRC to mediate between the idea of universal human rights and leaving space for reasonable disagreement, legitimate differences, and national or local cultural diversity. ${ }^{299}$ If the refusal of both institutions is rhetorical rather than substantive, it is submitted that it would be better if they openly acknowledged the doctrine. But on the evidence of its consistent practice the HRC's refusal to afford States a MoA is substantive rather than rhetorical. At the very least, as a universal human rights body, the HRC should be obliged to explain and justify in the clearest terms jurisprudence which knowingly departs from regional standards. If the ECtHR, which applies a MoA, still attracts charges of human rights imperialism, the HRC would appear to leave itself open for even greater criticism on that account.

An obvious difficulty in affording States a MoA which can be affected by presence or absence of consensus are the much larger number of States concerned (168 as compared to 47) and the even greater massive disparities between them than between members of the Council of Europe. There is arguably a greater risk or likelihood that the MOA doctrine could be used more to confirm prevailing social norms than to challenge them, ${ }^{300}$ but that may be an inherent element of a universal system. It remains to note that many of the arguments considered in this article would apply with equal force to the Inter-American ${ }^{301}$ and African regional human rights systems. ${ }^{302}$

\footnotetext{
${ }^{299}$ See Legg, supra n 00, on 'affording appropriate respect for local values in the states' implementation of their international human rights obligations', at 225.

${ }^{300}$ See Heinze, supra n 00, 289, n 32. He also observed that 'If United Nations bodies should ever adopt such a doctrine, seeking favorable developments in a significant number of States before recognizing rights, sexual minorities will have a long wait', at 290.

${ }^{301}$ See Candia, 'Comparing Diverse Approaches to the Margin of Appreciation: The Case of the European and the Inter-American Court of Human Rights' (9 March 2014), available at http://papers.ssrn.com/sol3/papers.cfm?abstract_id=2406705; Contreras, supra n 00 (argument that the Inter-American Court of Human Rights should afford states a MoA) . ${ }^{302}$ See H. Rubasha, 'Accommodating Diversity: Is the Doctrine of Margin of Appreciation as Applied in the European Court of Human Rights Relevant in the African Human Rights System?', 27 October 2006, available at http://repository.up.ac.za/bitstream/handle/2263/1228/rubasha_h_1.pdf?sequence=1
} 
Compare HRC in Faurisson v. France, Cmn No. 550/1998 - see my article on it - with the approach of ECtHR? [think results the sameish?] Lehideux and Isorni v. France, A. 24662/94 [GC], (1998).

E. Brems, 'Should Rights Shape Societies and their Values or should Societal Values Shape Rights? An Examination of the Case-law of the European Court of Human Rights' in Andras Sajo and Renata Uitz (eds), Constitutional Axiology, or Is There Anything behind/above the Constitution? 143 (Utrecht: Eleven Publishing, 20).

- the African Commission, too, referred to the margin of appreciation doctrine in the decision adopted during the ordinary session, which took place from 23 November to 7 December 2004, in the Garreth Anver Prince v. South Africa case. Although the

- Commission has not found a violation of the appellant's freedom of religion, whom, when arrested for possession of cannabis, invoked respect for the principles of the Rastafarian religion from which the use of cannabis follows, it underlined the necessity of a strict interpretation of the margin of appreciation of States. See (Rubasha 2006). 